\title{
A Survey of Musical Expectations in the Marine Forces Reserve Band stationed in New Orleans, Louisiana
}

\author{
Brandon Paul Carbonari \\ West Virginia University, bpcarbonari@mix.wvu.edu
}

Follow this and additional works at: https://researchrepository.wvu.edu/etd

Part of the Music Education Commons, Music Pedagogy Commons, Music Performance Commons, Music Practice Commons, and the Other Music Commons

\section{Recommended Citation}

Carbonari, Brandon Paul, "A Survey of Musical Expectations in the Marine Forces Reserve Band stationed in New Orleans, Louisiana" (2021). Graduate Theses, Dissertations, and Problem Reports. 10332.

https://researchrepository.wvu.edu/etd/10332

This Dissertation is protected by copyright and/or related rights. It has been brought to you by the The Research Repository @ WVU with permission from the rights-holder(s). You are free to use this Dissertation in any way that is permitted by the copyright and related rights legislation that applies to your use. For other uses you must obtain permission from the rights-holder(s) directly, unless additional rights are indicated by a Creative Commons license in the record and/ or on the work itself. This Dissertation has been accepted for inclusion in WVU Graduate Theses, Dissertations, and Problem Reports collection by an authorized administrator of The Research Repository @ WVU.

For more information, please contact researchrepository@mail.wvu.edu. 


\section{A Survey of Musical Expectations in the Marine Forces Reserve Band}

stationed in New Orleans, Louisiana

Sergeant Brandon P. Carbonari Research Document submitted to the School of Music at West Virginia University in partial fulfillment of the requirements for the degree of Doctor of Musical Arts In

Trombone Performance

H. Keith Jackson, DMA, Committee Chair Joshua Williamson, MM

Nina Assimakopoulas, MM

Jonas Thoms, MM

Music

Morgantown, West Virginia 2021

Keywords: Marine Band, Military Music, United States Marine Corps, Marine Forces Reserve, Musical Expectations Copyright 2021 Brandon P. Carbonari 


\section{A Survey of Musical Expectations in the Marine Forces Reserve Band stationed in New Orleans, Louisiana.}

\section{Brandon P. Carbonari}

This research document examines the musical expectations of United States Marines serving in the Marine Forces Reserve Band from 2017 to 2021. Chapter One of this study provides a detailed foundation of the musical and non-musical responsibilities of a United States Marine musician. Training regime, rehearsal schedule, and logistical area responsibilities will be described to help convey the full scope of duty. The source material for Chapter One includes dissertations, journal articles, published books, online sources, and interviews. Chapter Two provides results of a survey that was conducted with members of the band. The questions were designed to record the Marines' musical backgrounds and determine whether those backgrounds had an effect on their expectations of the musical aspects of being a US Marine musician. This chapter also contains interviews with Marines who led chamber groups within the unit. The interview questions gauge the Marines' level of prior training to lead an ensemble and it surfaces any potential for conflicts of interest between being a Marine and being a musician. The final chapter of this study analyzes the results of the surveys and interviews to determine how their musical expectations have been influenced by prior training.

Through analysis of the surveys and interviews, this document establishes musical expectations for one of the ten United States Marine Corps Fleet Bands. It displays a unique perspective through the voice of United States Marine Corps musicians and their viewpoints can serve as a valuable addition to future research in the field of military music. 


\section{Dedication}

This study is dedicated to the musicians of the United States Marine Corps who carry the musical tradition and warrior legacy of the world's most lethal fighting force. A special word of thanks to the Marine Forces Reserve Band for helping to mold the best version of myself. 


\section{Acknowledgements}

To my wife Kacey, thank you for providing me with everything I needed (and more) to complete this journey. You have stuck with me through my highest and lowest points. I am so thankful I get to share my joys, successes, failures, and celebrations with you. I cannot wait to see what the future holds for us.

To my family, your love and support throughout my life has allowed me the opportunity to have a career in music. Not everyone always understands what I am doing or why I am doing it, but you have always been incredibly supportive. This is your success as much as it is mine.

To Ms. Deborah Heiney and Mr. Craig Paine, for encouraging a timid and shy beginning trombonist and turning him into a cocky and naive trombone holder, thank you for pushing me to keep trying. Your support from behind the scenes has not gone unnoticed.

To Mr. Stephen McEuen, for your unwavering belief in me. Without it, none of this would have been possible. I wish you were here to share this with. I miss you terribly.

To Mr. Mark Lusk, for setting the foundation of my love for music. I will always be grateful for the music family you've created and for allowing me to be a part of it.

To Mr. Murray Crewe, our lessons together went beyond music. I will always cherish our time together. I wish you were here to share this with. I miss you terribly.

To Dr. Keith Jackson, it was your persistence and encouragement that helped me see this through to the end.

To Dr. Scott C. Tobias, for giving me the opportunity to pursue conducting. You never hesitated in taking me in as one of your own. For that, I will forever be indebted to you. Our brief time together has already helped create so many opportunities for me.

To Dr. Charles Youmans, for helping me understand the importance of scholarly writing. Your Strauss class I was a part of had such a positive impact on me, that I decided to pursue my DMA without any fear of writing a dissertation.

To Professor Virginia Thompson, we barely had the opportunity to work together. It was your encouraging and inspiring words that helped me decide to pursue my dream at West Virginia University. I wish you were here to share this with.

To Sergeant Lucy Warmbrodt, for helping me polish the original idea for this document over many nights filled with lots of debates and lots of food.

To Gunnery Sergeant Megan Harper, for helping me gain the courage and confidence to write about this profession which we care about so deeply. Hopefully this document will help others feel similarly. 
To both of my Editors, thank you for having my six.

To Dr. Louis Setzer and Dr. Christopher Brown, for being excellent role models, inspiring colleagues, and most importantly my closest friends. Watching your successes helped fuel my motivation. Thank you for keeping me sane. 
Table of Contents

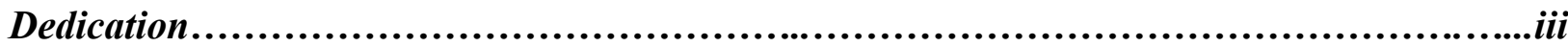

Acknowledgements..................................................................

List of Figures.................................................................................. vii

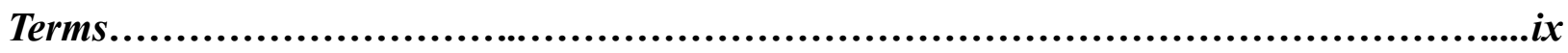

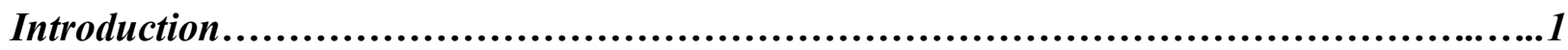

Review of Literature................................................................6

Scope and Limitation.................................................................

Research Methodology .................................................................9

Chapter 1: Responsibilities of Marine Musician................................................13

Section 1. Marine Corps MOS 5524.............................................13

Section 2. Logistical Area..........................................................17

Section 3. Training and Education....................................................19

Section 4. Additional Opportunities Available..........................................20

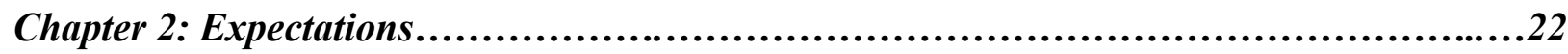

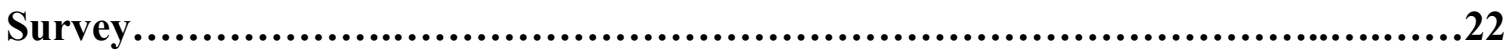

Interviews Interviews for ensemble leaders in the MFR Band from 2017 to

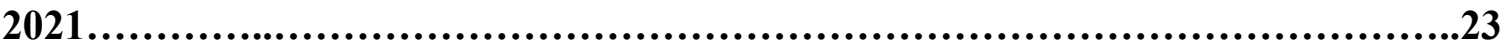

Chapter 3: Results.........................................................................24

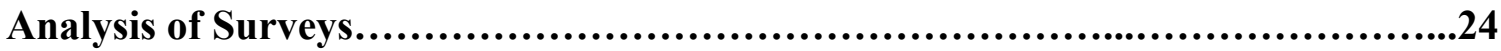

Comparing Interview Responses.................................................25

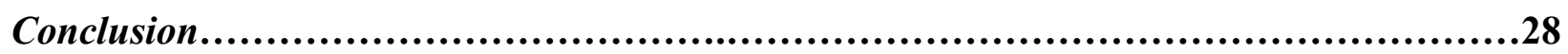

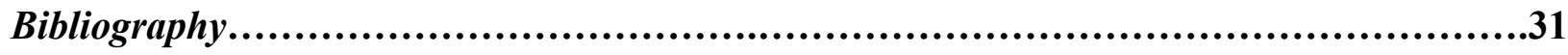

Appendix A: Survey Questions and Answers.................................................................35 
Appendix B: Interviews for ensemble leaders in the MFR Band from 2017 to

Sgt Morale Hoskins, tuba..............................................62

Sgt Breana Wiener, horn...........................................65

Sgt Lucy Warmbrodt, saxophone.......................................67

SSgt Jesse Sylvester, trombone........................................69

Sgt Patrick Box, trombone.......................................... 72

GySgt Megan Harper, oboe..........................................74

SSgt Dee Thomas, trumpet........................................... 77

CWO2 Eric Kyne, saxophone.............................................80 


\section{List of Figures}

Figure 1: Plan of the Day example: transcribed by Brandon Carbonari, 2021..................3 Figure 2: Plan of the Day Events and Explanations Table: created by Brandon Carbonari, 2021

Figure 3: Marines who volunteered to participate in the interview: created by Brandon

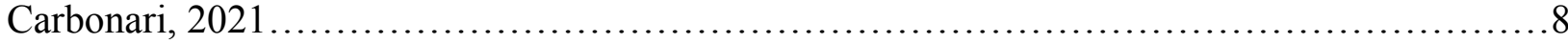

Figure 4: Assessment Rubric: From the U.S. Naval School of Music, 2021 ..................16

Figure 5: Memorized Music List: From the MFR Band Library, 2021 ...................17

Figure 6: Logistical Area and Explanation Chart: created by Brandon Carbonari, 2021 .....18

Figure 7: Pie Chart Answers to Question 1: From the survey Musical Expectations in the Marine Forces Reserve Band, 2021 ................................................ 35

Figure 8: Bar Graph Answers to Question 2: From the survey Musical Expectations in the Marine Forces Reserve Band, 2021 .36

Figure 9: Pie Chart Answers to Question 5: From the survey Musical Expectations in the Marine Forces Reserve Band, 2021

Figure 10: Bar Graph Answers to Question 6: From the survey Musical Expectations in the Marine Forces Reserve Band, 2021.

Figure 11: Pie Chart Answers to Question 7: From the survey Musical Expectations in the Marine Forces Reserve Band, 2021.

Figure 12: Pie Chart Answers to Question 12: From the survey Musical Expectations in the Marine Forces Reserve Band, 2021. 
Terms

- Marine Corps Orders (MCO) establishes United States Marine Corps policy or doctrine.

- Marine Administrative Message (MARADMINS) is an update or addendum to an MCO.

- Military Occupational Specialty (MOS) is a system that categorizes career fields. MOS 5524 is an enlisted musician in the United States Marine Corps.

- Calendar Year Training is online and in-person classes and lectures to be completed between January 1st and December 31st and as defined by MARADMINS: 694/20.

- Fiscal Year Training is online and in-person classes and lectures to be completed between October 1st and September 30th and as defined by MARADMINS: 694/20.

- Professional Military Education (PME) is a curriculum based on rank and billet designed to prepare a Marine to understand their role as a member of their rank and as defined by MCO 1553.4B PROFESSIONAL MILITARY EDUCATION

- Rifle Qualification is completed annually to re-qualify Marine with the service rifle and pistol as defined by MCO 3574.2K MARINE CORPS COMBAT MARKSMANSHIP PROGRAMS

- Swim Qualification is completed every 2-3 years for recertification or as described in MCO 1500.52D MARINE CORPS WATER SURVIVAL TRAINING PROGRAM (MCWSTP).

- Marine Corps Martial Arts Program (MCMAP) creates physically capable warfighters as defined by MCO 1500.59A MARINE CORPS MARTIAL ARTS PROGRAM (MCMAP). 
- CBRND Defense is an annual training which provides guidance on how to deal with chemical, biological, radiological, and nuclear operations as defined by MCO $3400.3 \mathrm{H}$ CHEMICAL, BIOLOGICAL, RADIOLOGICAL, AND NUCLEAR DEFENSE (CBRND) POLICY AND TRAINING.

- Special Duty Assignments (SDA) are opportunities for Marines to temporarily leave their MOS and serve as a recruiter, drill instructor, or embassy guard detachment commander and as defined by MCO 1326.6 CH-1 SELECTING, SCREENING, AND PREPARING ENLISTED MARINES FOR SCREENABLE BILLETS AND INDEPENDENT DUTY ASSIGNMENTS (SCREENMAN).

- Marine Combat Instructor of Water Survival (MCIWS) manages established procedures to administer USMC swim qualifications.

- Combat Marksmanship Coach manages established procedures to administer USMC marksmanship qualifications.

- Martial Arts Instructor (MAI) manages established procedures to administer USMC MCMAP qualifications.

For the purpose of this study, the remaining terms will be defined through the lens of the United States Marine Corps Marine Forces Reserve Band

- Billet is a specific personnel position or assignment.

- Band Officer (BO) is the Officer in Charge (OIC) of the unit. It is always a Warrant Officer who is in charge of the Marine Corps Fleet Bands. Has the option to conduct any of the ensembles in the unit. 
- Bandmaster (BM) is the highest ranking enlisted Marine in the unit and serves as the Staff NCOIC.

- Drum Major (DM) is in charge of all rehearsals, ceremonies, and performances which require a Drum Major.

- Enlisted Conductor (EC) is in charge of all rehearsals, ceremonies, and performances which require a conductor.

- Small Ensembles Leader (SEL) manages small ensembles within the unit.

- Instrument Repair Technician (IRT) is in charge of repairing instruments and the budget of the unit.

- Platoon Sergeant is a billeted position held by an enlisted Marine who manages three to four squads and reports to the band leadership/staff.

- Squad Leader is a billeted position who manages three to four fireteams and reports to the Platoon Sergeant.

- Fire-team Leader is a billeted position who manages a fire-team, a group of three Marines, and reports to their squad leader.

- Logistical Area is a separate responsibility in addition to your Marine and musician duties. Your logistical area assignment will help the unit succeed administratively.

- Non-Commissioned Officer in Charge (NCOIC) signifies a Marine who has limited authority over others in a specific area. An NCOIC is appointed to manage a logistical area. 
"One day you will all die. And I will die too. The only difference is I will die as a Marine." Sergeant Major Troy Black

19th Sergeant Major of the Marine Corps 


\section{Introduction}

To understand the Marine Corps'philosophy of warfighting, we first need an appreciation for the nature of war itself-its moral, mental, and physical characteristics and demands. A common view of war among Marines is a necessary base for the development of a cohesive doctrine because our approach to the conduct of war derives from our understanding of the nature of war. ${ }^{1}$

This is the introduction to MCDP 1 Warfighting, the first book given to Marines during Marine Combat Training (MCT). MCT is a one month combat skills training regime for all noninfantry Marines. This training helps reinforce the phrase, "every marine is a rifleman." As a musician in the United States Marine Corps, it is mandatory to complete this training and many more requirements intended to help develop well-rounded Marines. Specific music training is either completed prior to enlistment, or it is conducted at the Naval School of Music in Virginia Beach, Virginia. Once a Marine musician arrives at their unit, they are expected to improve or at least maintain their playing ability. The warfighter and musician ethos' are two contrasting forces that combine to create the Marine musician and describing the responsibilities and duties helps to set the foundation for musical expectations for a musician in the United States Marine Corps.

The Marine Forces Reserve (MFR) Band is stationed at the Marine Corps Support Facility in New Orleans, Louisiana. It was established on October 1st, 1978 and is composed of fifty active duty Marines. Their primary mission is to support the Fourth Marine Division, Fourth Marine Aircraft Wing, Fourth Marine Headquarters Group, and the Fourth Marine Logistics Group. Essentially, the MFR Band is in charge of military performances in support of Marine

\footnotetext{
${ }^{1}$ United States Marine Corps. MCDP 1 Warfighting. Wildside Press, 1997.
} 
reserve units across the country. ${ }^{2}$ The MFR Band also performs in over two hundred and eighty concerts, parades, and ceremonies across the country. Some of these performances like Mardi Gras (New Orleans, Louisiana), the Houston Rodeo and Livestock Show (Houston, Texas), and Fiesta Days Celebration (San Antonio, Texas), are annual occurrences, while others, like the Super Bowl XLVII (New Orleans, Louisiana), Country Music Awards Festival (Nashville, Tennessee), and the Virginia International Tattoo (Norfolk, Virginia) are singular high profile performances in which the unit has participated.

The typical daily schedule for a Marine in the MFR Band provides insight into the varying responsibilities of the job and paints the picture of the expectations of various duties. Figure 1 shows an example of a partially redacted "Plan of the Day" (POD) while Figure 2 provides an explanation of each POD event.

While these schedules may describe a routine that is filled with rehearsals and performances, that is not always the case. Professional Military Education (PME) is also a large focus for the Marine musician. ${ }^{3}$ For example there are annual and fiscal year training requirements that need to be completed routinely and balanced with specific training required for each rank. There are also opportunities to perform collateral and extra duties outside of one's Military Occupational Specialty (MOS). Those additional duties include recruiting, embassy guard detachment, and drill instructor. Lastly, there are opportunities to become a rifle coach, swimming instructor, and martial arts instructor, adding to one's responsibility and helping to create a more well rounded Marine.

\footnotetext{
2 Sullivan, Jill M. "Women Music Teachers as Military Band Directors during World War II.” Journal of Historical Research in Music Education, October 2017.

3 Bolin, Duane. "New Marine Corps Doctrine Promotes Education \& Training." DAC Worldwide, August 2020. Accessed October 27th, 2021. https://dacworldwide.com/new-marine-corps-doctrine-promotes-education-training/
} 
Subj: PLAN OF THE DAY FOR

\section{DNCO:}
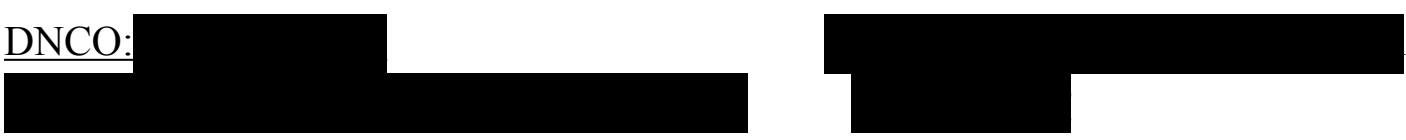

0730 Liberty Expires / Muster / PT / PT Gear (PltSgt)

0830 Recovery Time

0930 Sectionals

Change of Command Ceremony - BQ - BD"B" (Sgt Carbonari)

1030 Field Drill / Ceremonial Band (DM / EC)

1130 Chow

1300 Concert Band Rehearsal (EC)

1400 Small Ensembles Rehearsal "C"

- A - Logistical Time

1500 Police Call

1515 Liberty Call / Muster (PltSgt)

\section{Appointments:}

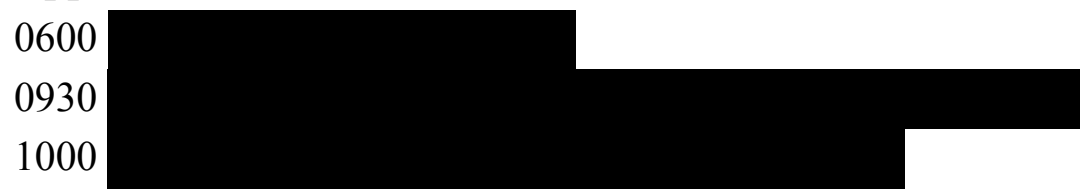

\section{Notes:}

Figure 1: Plan of the Day example: transcribed by Brandon Carbonari, 2021. 


\begin{tabular}{|l|l|l|l|}
\hline POD Event & Explanation & POD Event & Explanation \\
\hline Muster & $\begin{array}{l}\text { morning formation where the } \\
\text { Platoon Sergeant can take } \\
\text { accountability of Marines in }\end{array}$ & Chow & $\begin{array}{l}\text { time set aside to eat lunch } \\
\text { and take care of personal } \\
\text { tasks }\end{array}$ \\
\hline $\begin{array}{l}\text { Physical } \\
\text { Training (PT) }\end{array}$ & $\begin{array}{l}\text { can be done on an individual } \\
\text { basis, as a squad, or as a unit }\end{array}$ & Concert Band & $\begin{array}{l}\text { focuses on wind band } \\
\text { literature }\end{array}$ \\
\hline Recovery time & $\begin{array}{l}\text { gives the unit an opportunity to } \\
\text { shower, clean up, and get ready } \\
\text { for the workday }\end{array}$ & $\begin{array}{l}\text { Small } \\
\text { Bnsembles A, and C }\end{array}$ & $\begin{array}{l}\text { opportunity for small } \\
\text { ensembles to rehearse }\end{array}$ \\
\hline Sectionals & $\begin{array}{l}\text { instrument sections get together } \\
\text { to rehearse and prepare for } \\
\text { upcoming commitments }\end{array}$ & Logistical Time & $\begin{array}{l}\text { opportunity to complete } \\
\text { administrative } \\
\text { responsibilities }\end{array}$ \\
\hline Field Drill & $\begin{array}{l}\text { outdoor rehearsal where the } \\
\text { focus of effort is geared } \\
\text { towards marching and playing } \\
\text { for a ceremony or parade }\end{array}$ & Police call & $\begin{array}{l}\text { time for Marines to tidy } \\
\text { up their workspaces in } \\
\text { preparation for the } \\
\text { following workday }\end{array}$ \\
\hline $\begin{array}{l}\text { Ceremonial } \\
\text { Band }\end{array}$ & $\begin{array}{l}\text { rehearsing the music used in an } \\
\text { upcoming ceremony or parade } \\
\text { Muster }\end{array}$ & $\begin{array}{l}\text { Platoon Sergeant and } \\
\text { Staff members to } \\
\text { communicate information } \\
\text { to the entire unit before } \\
\text { leaving for the day }\end{array}$ \\
\hline
\end{tabular}

Figure 2: Plan of the Day Events and Explanations Table: created by Brandon Carbonari, 2021.

The fifty Marines of the MFR Band form seven ensembles that are expected to be ready to perform at a moment's notice. The MFR Concert Band utilizes the full unit when performing contemporary, traditional, and non-traditional wind band literature. ${ }^{4}$ The MFR Ceremonial Band plays marching instruments when performing in ceremonies, parades, and everything inbetween. The MFR Big Band uses traditional jazz band instruments to perform everything from

\footnotetext{
${ }^{4}$ Grames, Ronald E. "Elgar and His Peers: The Art of the Military Band.” The Magazine for Serious Record Collectors, January/ February 2018.
} 
jazz standards to modern fusion. ${ }^{5}$ The MFR Brass Band is formed from eight Marines and their styles range from traditional New Orleans brass band music to modern interpretations of the genre. The MFR Jazz Combo uses anywhere from three to six Marines to perform all styles of jazz. The MFR Woodwind and Brass Quintets perform in military ceremonies and civic events. Each of these ensembles are responsible for carrying out the unit's missions while maintaining a wide range of repertoire and performances.

Chapter One analyzes the specific responsibilities of a Marine musician in the Marine Forces Reserve Band stationed in New Orleans, Louisiana. Here we will elaborate on MFR Brass Quintet's musical and nonmusical duties while describing PME requirements in detail. In the final section of Chapter One we will describe additional opportunities that Marine musicians have to lead, coach, train, and contribute to the Marine Corps while progressing in their careers.

Chapter Two of this study details the results of a survey created to gauge the musical expectations of Marines in the MFR Band from the years 2017-2021. The survey questions are designed to give a better understanding of expectations to all considering enlisting in the United States Marine Corps Music Program. The chapter also reveals transcribed interviews with Marines who led chamber groups within the unit during that time frame. The interview questions are designed to give insight into the training and leadership opportunities of a small ensemble leader.

Chapter Three explores the answers and searches for trends across the respondents and interviewees. These will be compared to see if there are any similar answers and to determine if they can shape one's musical expectations. The surveys and interviews provide us insight into whether the warrior mindset and musician mindset are both cultivated in the Marine Corps to meet or exceed expectations.

\footnotetext{
5 Hale, James. “Military Band Alums Dominate George Mason Faculty.” Downbeat, February 2019.
} 


\section{Review of Literature}

Compared to the "President's Own" United States Marine Band, The United States Marine Corps Fleet Bands receive less publicity and recognition. The Marine Forces Reserve Band is primarily focused on serving the reserve component of the Marine Corps, however that does not make their mission less important.

Originally, this document was intended to be a case study. After reading William Ellet's The Case Study Book 6 and Robert Yin's Case Study Research: Design and Methods ${ }^{7}$, it was determined that the intended research did not lend itself to a case study. Survey and interview questions were determined as the best method to obtain examples of musicality within the band. After this was decided, initial research revealed that there is virtually no scholarly writings specifically regarding the fleet bands of any branch of the Armed Forces. Writings, understandably so, solely focus on the premiere bands and dissertations and theses found in ProQuest revealed only a few relevant results. West Virginia University Library databases, specifically Academic Search Complete and JSTOR, had a plethora of military band specific articles. However, there was still a limited amount of articles which pertained to this topic. Surprisingly, several military magazines not found in the West Virginia University Libraries had very useful articles about life in a military band.

John Jay McNeal's When Identities Collide: A Marine Musician in the Field from the Journal of Military Experience ${ }^{8}$, details the personal struggles of Lance Corporal McNeal during

\footnotetext{
6 Ellet, William. The Case Study Handbook: How to Read, Discuss, and Write Persuasively About Cases. Brighton, MA: Harvard Business Review Press, 2007.

7 Yin, Robert K. Case Study Research: Design and Methods. Los Angeles, CA: Sage Publications, Inc; Fifth Edition, 2013.

${ }^{8}$ McNeal, John Jay. "When Identities Collide: A Marine Musician in the Field.” The Journal of Military Experience, 2012.
} 
his time as part of the Quantico Marine Corps Band. This article discusses how his focus is always changing from the needs of the military to the needs of the band.

Kristine Froeba's article, Marine Corps Forces Reserve Band Once Again Takes the Streets at New Orleans Mardi Gras from the Marine Corps Times ${ }^{9}$, examines the close relationship the Marine Corps and the city of New Orleans has developed. She also details the busy schedule Marines maintain during the Carnival season.

Bruce P. Gleason's, Military Music in the United States: A Historical Examination of Performance and Training from the Music Educators Journal10, examines military music training, traditions, and explores the origin of military music. This detailed history provides excellent insight into the influence military bands had on the public education system in the United States.

Neal Snyder's, What About a Military Band? journal article found in Teaching Music11, details career opportunities for musicians interested in military bands. Topics covered include enlistment procedures, basic training, and school of music training.

J. G. Miller's, A Successful Military Band Audition from Horn Call: Journal of the International Horn Society ${ }^{12}$, is an interview with the U. S. Army Band "Pershing's Own" hornist, Staff Sergeant Pat Furlo. In this interview, SSG Furlo discusses his musical upbringing which led to his successful audition and details the audition process for the Army Band.

\footnotetext{
${ }^{9}$ Froeba, Kristine. "Marine Corps Forces Reserve Band Once Again Takes the Streets at New Orleans Mardi Gras.” Marine Corps Times, February 2020.

10 Gleason, Bruce P. "Military Music in the United States: A Historical Examination of Performance and Training." Music Educators Journal, March 2015.

11 Snyder, Neal. “What About A Military Band?” Teaching Music, April 1996.

12 Miller, J. G. “A Successful Military Band Audition.” Horn Call: The Journal of the International Horn Society, October 2016.
} 


\section{Scope and Limitation}

The primary subjects of the survey are current and former members of the Marine Forces

Reserve Band from the years 2017 to 2021 . The unit maintains fifty active duty Marines and is always working through changeover. At any point during the year, there were about ten Marines leaving and ten to replace them. Having this high rate of turnover left opportunities for other Marines to fill in a need for the unit.

The interview participants were small ensemble leaders of the Marine Forces Reserve Band from the years 2017 to 2021 . These participants must also have led a small ensemble through at least twenty performances during the same four year span. That timeframe was determined to ensure the highest rate of participation for the interviews.

\begin{tabular}{|l|l|}
\hline Rank / Name & Key Roles / Qualifications \\
\hline $\begin{array}{l}\text { Chief Warrant Officer 2 Eric } \\
\text { Kyne }\end{array}$ & $\begin{array}{l}\text { OIC of the Marine Forces Reserve Band since 2019. } \\
\text { CWO2 Kyne is the primary conductor of the Marine } \\
\text { Forces Reserve Band. }\end{array}$ \\
\hline Staff Sergeant Jesse Sylvester & $\begin{array}{l}\text { The Non-Commissioned Officer in Charge of the } \\
\text { Marine Forces Reserve Brass Quintet since 2020. }\end{array}$ \\
\hline Sergeant Patrick Box & $\begin{array}{l}\text { The acting Drum Major of the Marine Forces } \\
\text { Reserve Band since 2019. He primarily directs the } \\
\text { MFR Ceremonial Band and has conducted the MFR } \\
\text { Concert Band. }\end{array}$ \\
\hline Sergeant Lucy Warmbrodt & $\begin{array}{l}\text { The Non-Commissioned Officer in Charge of the } \\
\text { Marine Forces Reserve Brass Band since 2020. }\end{array}$ \\
\hline Staff Sergeant Dee Thomas & $\begin{array}{l}\text { The Non-Commissioned Officer in Charge of the } \\
\text { Marine Forces Brass Quintet from 2017 to 2020. }\end{array}$ \\
\hline $\begin{array}{l}\text { Gunnery Sergeant Meghan } \\
\text { Harper }\end{array}$ & $\begin{array}{l}\text { The former Enlisted Conductor of the Marine Forces } \\
\text { Reserve Band from 2018 to 2020. }\end{array}$ \\
\hline
\end{tabular}




\begin{tabular}{|l|l|}
\hline Sergeant Breana Wiener & $\begin{array}{l}\text { The Non-Commissioned Officer in Charge of the } \\
\text { Marine Forces Reserve Rock Band from 2019 to } \\
\text { present. }\end{array}$ \\
\hline Sergeant Morale Hoskins & $\begin{array}{l}\text { The Non-Commissioned Officer in Charge of the } \\
\text { Marine Forces Reserve Brass Band, Jazz Fusion } \\
\text { Ensemble, and Brass Quintet since 2019. }\end{array}$ \\
\hline
\end{tabular}

Figure 3: Marines who volunteered to participate in the interview: created by Brandon Carbonari, 2021.

\section{Research Methodology}

Three primary research methods will be used to facilitate this study. These methods are literature reviews, survey dissemination/analysis and personal interviews/ analysis. Information will be obtained via scholarly articles, dissertations, and recordings. Only highly credible resources were consulted and used for this particular section of the research. An acute examination of these materials will be used to identify authentic, relevant, and pertinent information.

Surveys will be sent to all current members of the Marine Forces Reserve Band and any offered to any former members in the 2017 to 2021 timeframe. All of the subjects are still currently active duty and/or part of the Individual Ready Reserve component of the United States Marine Corps. The following survey questions were asked of the subjects: In congruence with the guidelines of human research through the West Virginia University Research Compliance Administration, I have completed the Institutional Review Board training as well as the Social \& Behavioral Research Investigator Module to appropriately complete the survey portion of this document. This training provided pertinent information for human research as well as promotes respect and rights for all individuals interviewed. 
These questions were created and offered to the Marine Forces Reserve Band in the form of a survey:

1. What is your highest level of formal education (answers provided: High School, some college, college degree, graduate degree)? Is your degree in music (n/a, yes, no)?

2. How long have you been in the USMC (options provided: 1-4 years, 5-8 years, 9-12 years, 13-16 years, 17 years up and more)?

3. How long have you been at your current duty station (options provided: 1 year, 2 years, 3 years, 4 years)?

4. How many USMC bands have you served in?

5. Were you a professional musician and/or music educator prior to enlisting (yes or no, if yes please elaborate)

6. What is the "expectation versus reality" of being a Marine musician?

7. What were/are you looking for in being a Marine musician?

8. What are examples of how being a Marine reinforces being a musician?

9. Do you feel being a Marine conflicts with being a musician? If so, please provide examples.

10. What is one message you would give to potential Marine musicians?

11. What experience(s) with the USMC best epitomizes your service?

Personal interviews will be administered to obtain a significant portion of information relative to this topic. These interview questions are intended to give insight into the level of training received to help prepare for a role as a leader of a military ensemble and their musical decision making processes. The following interview questions will be asked of current and 
former MFR Band small ensemble leaders. In congruence with the guidelines of human research at West Virginia University Research Compliance Administration, I have completed the Institutional Review Board training as well as the Social \& Behavioral Research Investigator Module to appropriately complete the interview portion of this document. This training provided pertinent information for human research as well as promotes respect and rights for all individuals interviewed.

These questions were created and offered to the small ensemble leaders of the unit in the form of an interview:

1. Did you have experience leading/conducting ensembles prior to your time in the USMC? If so, please elaborate?

2. What training has been provided by the USMC to help you prepare for your role as an ensemble leader?

3. Please elaborate on any formal or informal musically relevant training opportunities you have experienced.

4. What opportunities are available for you to lead traditional and non-traditional ensembles?

5. As an ensemble leader, do you feel that you have control over personnel, repertoire, and other musical decisions?

6. Are you able to program musically fulfilling repertoire?

7. Is there any reason the USMC would preclude you from making programmatic decisions?

8. What does being a well-rounded Marine musician mean to you? 
9. What kind of doors does being a well-rounded Marine musician open

(professionally and musically)? 


\section{Chapter 1: Responsibilities of a Marine Musician}

\section{Section 1. Marine Corps MOS 5524}

As the keepers of tradition, the primary mission of the Marine Forces Reserve Band is in support of Marine Forces Reserve units across the country. Recruit training, Marine Combat Training, and the Naval School of Music are the three training environments for a Marine musician before reaching their first duty station. ${ }^{13}$ Music training is provided at the Naval school of Music. ${ }^{14}$ However, the option to 'test-out' the School of Music is available to those who score high enough on an audition.

Once in their assignment, and after a thirty day check-in period, a new Marine is assigned to ensembles and to a logistical area. They integrate into a unit that is training for performances depending on the time of year. Specific to the MFR Band, the Carnival Season performances and Mardi Gras parades are annual traditions. The unit also conducts two recruitment tours working with recruiting stations, high schools, universities, and communities across the United States. ${ }^{15}$ Additionally, a new Marine should expect that the MFR Band may be requested to supplement other USMC Reserve units in need of musical support. ${ }^{16}$ In addition to national performances, the unit also supports local events helping to ensure a close relationship with the community. ${ }^{17}$

\footnotetext{
13 Phillips, Dave. "Military is Being Asked to March to A Less Expensive Tune.” New York Times, August 2016.

14 Welborn, Daniel C. “The Soldier-Musician: Professional Opportunities for Recent Instrumental Graduates.” Music Educators Journal, March 2015.

15 Wyman, Richard. "Mission Possible: The U. S. Coast Guard Band and Music Education.” Music Educators Journal, March 2015.

16 Sullivan, Jill M. "Women Music Teachers as Military Band Directors during World War II.” Journal of Historical Research in Music Education, October 2017.

17 Platt, R. Eric. "Marching in Step: Patriotism and the Southern Catholic Cadet Movement." Catholic Historical Review, 2016.
} 
A typical POD contains rehearsals and performances simultaneously scheduled alongside non-musical responsibilities such as physical training, logistical time and police call. Ensembles rehearse every day during and outside of listed work hours. Small ensembles will maintain a standard set list ready to be performed at a moment's notice even though new set lists are constantly being introduced and developed. Marines are also given opportunities to arrange music for the unit. ${ }^{18}$ There is time built into the schedule for instrument sections to rehearse or for personnel to practice individually. That time can be used for improved proficiency on one's instrument or to help prepare a section for upcoming rehearsals and performances.

Individual Practice (IP) and time put in outside of the POD are used to gain proficiency on your instrument. Each rank has a minimum playing score they must maintain on their primary instrument. As seen in Figure 3, assessments are based on several contributing factors evaluated by members of the MFR Band Leadership. Assessment repertoire will vary depending on the will of the Band Officer. Contrasting styles, sight reading, and multiple genres are expected to be a part of a Marine's selection of music for an assessment.

The MFR Band also has the resources to provide instruments for the Marines in the unit. ${ }^{19}$ Incoming Marines are issued instruments for all of the ensembles in which they perform. For example, a trombonist will be issued a trombone for concert, ceremonial, and jazz bands. Accessories such as reeds, mouthpieces, cases, and instrument stands are also provided. Although not always able to accommodate, Marine's may request specific pieces of equipment that are not immediately available.

Being a Marine musician is a unique position as it is one of the rare specialties where a civilian enlists in the USMC with a skill set that is already developed but it is up to the Marine

\footnotetext{
18 Barnes, Julian E. "Short of Military Brass, NATO Band Soldiers On.” Wall Street Journal, July 2016. Accessed October 12th, 2021. https://www.wsj.com/articles/short-of-military-brass-nato-band-soldiers-on-1467910391

19 Mockenhaupt, Brian. "Band Aid.” Atlantic, May 2012.
} 
musician to continually improve their proficiency on an instrument. Additionally, it is important to note that there are many more aspects to the job that help create a well-rounded Marine musician and the Marine Corps relies on small unit leadership to cultivate new and better leaders. ${ }^{20}$

20 Athey, Philip. “Gunny Exhibits ‘Small-Unit Leadership' for Marines Returning from Afghanistan.” Marine Corps Times, October 2021. Accessed October 9th. 2021.https://www.marinecorpstimes.com/news/your-marine-corps/2021/10/01/gunny-exhibitssmall-unit-leadership-for-marines-returning-from-afghanistan/ 


\section{NAVAL SCHOOL OF MUSIC TROMBONE}

ASSESSMENT

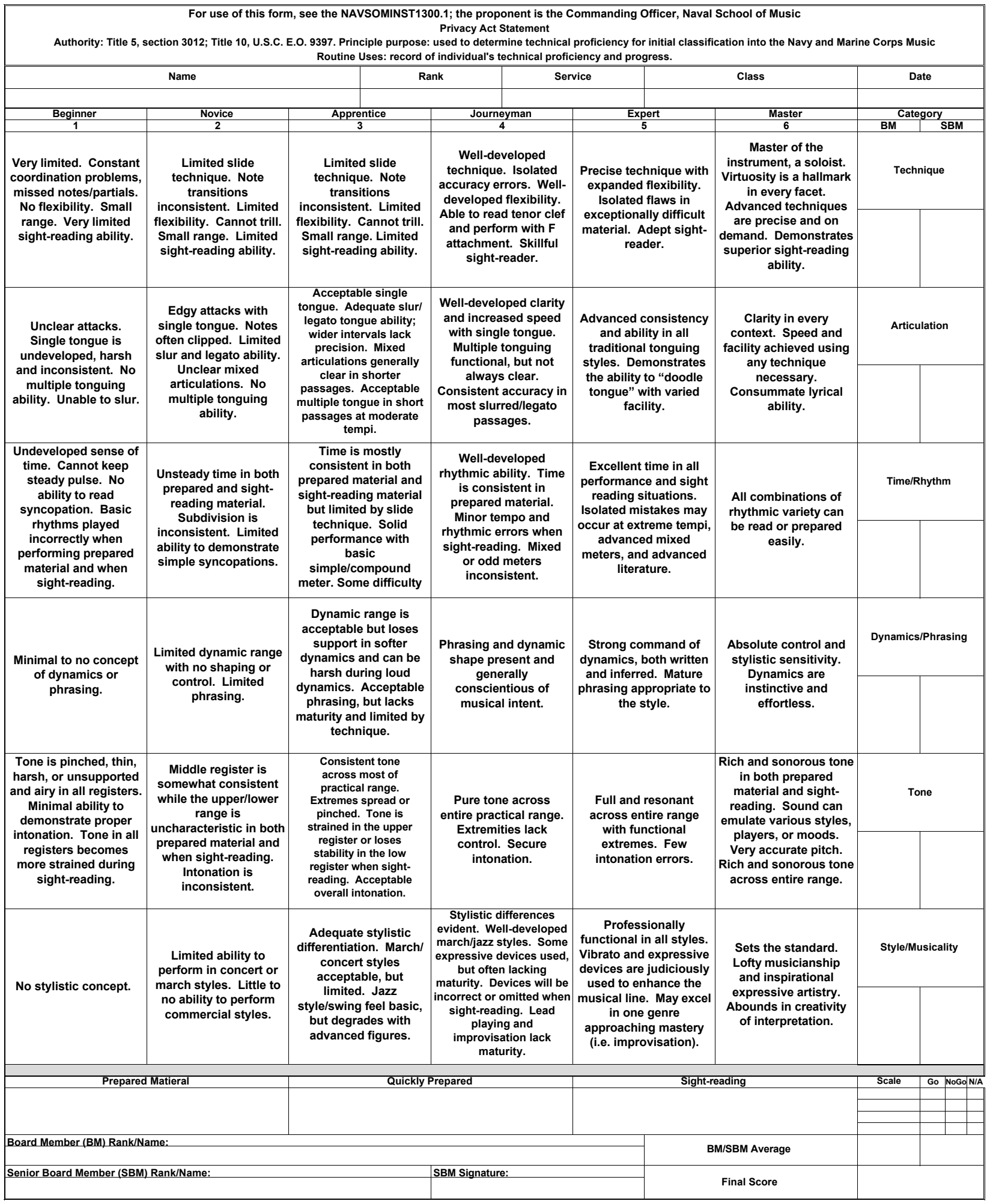

NAVSOM 1300/09 (Rev. Jun 2017)

Figure 4: Naval School of Music Trombone Assessment: NAVSOMINST 1300.1, 2021 


\section{Section 2. Logistical Area}

The Marine Forces Reserve Band is a unit of several ensembles which perform in a variety of situations. These Marines musicians assigned to this unit also have administrative, or logistical, responsibilities to perform in addition to their musical duties. ${ }^{21}$ These "log areas" may not carry the pressure of performing for audiences but they do have their own sets of challenges.

However, before being assigned an administrative duty, a new Marine will have thirty days to memorize music from the Memorized Music List set by the Enlisted Conductor. ${ }^{22}$ See Figure 2 below for an example of the Memorized Music List. It is during this time that the new Marine is introduced to each area, interviewed by staff, and from that interview be assigned to an area which best suits the Marines abilities and experiences. Requests to work in a specific "log area" will be considered but the needs of the unit will trump the desires of the individual.

\begin{tabular}{|l|l|}
\hline \multicolumn{2}{|l|}{20210401 Memorized List } \\
\hline Adjutant's Call & House of the Rising Sun (Slow March) \\
\hline Anchors Aweigh & Marines' Hymn \\
\hline Attention & National Emblem (Trio) \\
\hline Auld Lang Syne (Trio) & Officer of the Day \\
\hline Battle Cry of Freedom & Ruffles and Flourishes \\
\hline Bourbon Street Parade & Semper Fidelis \\
\hline C.M.T.C. & South Rampart Street Parade \\
\hline Eagle Squadron & Stars and Stripes Forever, The \\
\hline Eternal Father & Star Spangled Banner, The \\
\hline Flag Officer's March & You're A Grand Old Flag \\
\hline General's March & \\
\hline
\end{tabular}

Figure 5: Memorized Music List: From the MFR Band Library, 2021.

${ }^{21}$ Lo, Patrick. “Jane Cross, Master Gunnery Sergeant, USMC, Chief, U.S. Marine Band Library.” Music Reference Services Quarterly, July-September 2018.

22 Ibid 


\begin{tabular}{|l|l|}
\hline Logistical Area & Description \\
\hline Supply & $\begin{array}{l}\text { in charge of providing instruments, } \\
\text { uniforms, and other equipment required }\end{array}$ \\
\hline Administration & $\begin{array}{l}\text { schedules short and long term plans and } \\
\text { processes performance requests }\end{array}$ \\
\hline Information Systems Coordinators & $\begin{array}{l}\text { ensures technology in the MFR Band } \\
\text { Annex is up to date and in working order }\end{array}$ \\
\hline Defense Travel System & $\begin{array}{l}\text { creates reservations and confirms travel } \\
\text { plans for the unit }\end{array}$ \\
\hline Transportation & $\begin{array}{l}\text { in charge maintaining the bus, providing } \\
\text { drivers, and ensuring the unit has proper } \\
\text { transportation to and from performances }\end{array}$ \\
\hline Training & $\begin{array}{l}\text { ensures Marines are up to date on } \\
\text { trainings and exercises }\end{array}$ \\
\hline Public Affairs Office & controls the unit's media presence \\
\hline Library & manages the music inventory \\
\hline Recording Studio & $\begin{array}{l}\text { manages the sound board and recording } \\
\text { equipment for the unit }\end{array}$ \\
\hline
\end{tabular}

Figure 6: Logistical Area and Explanation Chart: From the MFR Band Library, 2021.

These logistical areas are usually led by a Non-Commissioned Officer (NCO) and are critical to the band's success. Each NCO in charge of a "log area" reports to a specific MFR Band Leadership Staff member and these personnel determine if there are opportunities to change a Marine musician's log area based on the needs of the unit. Whether Log Time is scheduled on the POD or not, these "log areas" need daily attention to help ensure the mission of the MFR Band is accomplished. Being a self-run organization, these collateral duties are essential to the success of the unit. 


\section{Section 3. Education and Training}

The Marine Corps has recently put more emphasis on creating a culture of learning. ${ }^{23}$ They are putting an emphasis on education, training, and continued learning as they look for ways to intellectually gain an advantage in warfighting. ${ }^{24}$ This focus on developing the intelligent warrior is proven by the volume of training and education that Marines participate in throughout the year. ${ }^{25}$

There are two types of annual training required by the Marine Corps. One is Calendar Year Training which is required to be completed every year between January 1st and December 31 st. ${ }^{26}$ The training is online courses which deal with violence prevention, tobacco cessation, terrorism awareness, and operational security. Fiscal Year Training is completed each year between October 1st and September 30th. The online portion of these classes discuss topics such as human trafficking and cyber awareness.

Calendar and fiscal year training requirements also include lecture style and field training exercises. Lectures educate Marines on topics like sexual harassment, risk management, social media misconduct, hazing, and sexual assault prevention while field training includes the Physical Fitness Test, Combat Fitness Test, water survival, rifle and pistol marksmanship, and CBRN defense. Annual training is introduction level courses designed to set a foundation of understanding for the entire Marine Corps. There are also higher level courses and training opportunities which build on these calendar and fiscal year training requirements.

\footnotetext{
23 Herbert, David G. “Another Perspective: Militarism and Music Education.” Music Educators Journal, March 2015.

24 Correll, Diana Stancey. "A Culture of Learning: Why the Marine Corps is Promoting Education, Training in its New Doctrine." Marine Corps Times, May 2020.

25 United States Marine Corps. MCDP 7 Learning. Independent Publisher, 2020.

26 United States Marine Corps. “Updated Enlisted PME Requirements By Grade.” MARADMINS 474/21, September 2021.
} 
Some ranks in the Marine Corps have additional training requirements which need to be completed before becoming eligible for promotion. For example, E-3 and E-4 each have an online and an in-person curriculum. ${ }^{27}$ After completing the online portion of the requirement, a Marine is temporarily removed from the unit and placed into a temporary unit of Marines in the same rank to complete the in-person requirement. They spend the next week or more learning their expectations, building leadership skills, and becoming more physically fit. After graduation from this rank-specific course, they return to their unit as a stronger leader and a more knowledgeable resource.

In addition to MOS proficiency, training and education are two additional pillars that create a well-rounded Marine. MCMAP, rifle training, and swim qualification help create the warrior ethos sought after by those who are seeking career longevity. Being proficient in these areas helps Marines take initiative and exploit an enemy's weakness. ${ }^{28}$ With higher rank comes higher expectations and responsibility. The warrior mindset developed through the various levels of training is leaned on when opportunities to lead other Marines arise.

\section{Section 4. Additional Opportunities Available}

Marines are considered to be a force-in-readiness. MCDP 3 goes into great detail about how Marines must be up to date on training and flexible enough to respond to any given situation. ${ }^{29}$ The Marine Corps offers a variety of opportunities to venture outside of one's occupational field and into situations that require leadership, training, coaching, teaching and recruiting.

\footnotetext{
27 Ibid

28 Yi, Capitan Jamison. "MCMAP and the Marine Warrior Ethos.” Military Review, November-December 2004.

29 United States Marine Corps. MCDP 3 Expeditionary Operations. Independent Publisher, 2018.
} 
Opportunities also exist to volunteer to be a Faculty Advisor (FA) for the in-house Lance

Corporal and Corporal training courses are available for NCO's. Those selected are temporarily removed from the unit to lead Marines in physical training, classroom environments, and everything in between. Upon graduation of the class, FA's are returned to their unit.

The rifle range, swimming qualification, CBRN training, PFT, and CFT, are all training events which require coaches and instructors. To become a trainer, instructor, or coach, a Marine will again leave their unit and attend a training course dedicated to that specific craft. Upon successful completion of the training course, a Marine would be eligible to help conduct training events for their own base of operations. These are some of the duties that fall outside of the musician aspect of being a Marine musician.

Marines, who are eligible, can volunteer for a three year Special Duty Assignment (SDA). SDA's include recruiter, drill instructor, or embassy guard. All three require their own training course. Should one select this route, SNM is placed on temporary leave from the band and begins training for the specific SDA. Upon completion of the assignment, the Marine will be sent back into the band occupational field.

None of these billets are required of a Marine but there will always be a need for them as long as Marines are training. Volunteering to become a coach or trainer will have some added benefits like financial compensation. These opportunities are recommended for those who are looking to move ahead of their peers as all of these opportunities listed are considered advantageous to those seeking promotion. ${ }^{30}$

30 Harkins, Gina. "Marines Who Volunteer for Special Duty Assignments Can Earn Thousands With New Bonus." Military.com, October 2020. Accessed October 30, 2021. https://www.military.com/daily-news/2020/10/29/marines-who-volunteer-specialduty-assignments-can-earn-thousands-new-bonus.html 


\section{Chapter 2: Expectations}

To formulate a full set of expectations that a musician wanting to join the Marines should consider, we call upon personal experience and the canvassing of current and former Marines. This canvassing was performed through specifically developed surveys and through interviews of certain Marine personnel. The surveys were used to drive concise, specific answers to questions regarding experience, training and expectations. The interviews were conducted, to allow for a more free flowing generation of ideas and advice. Throughout this overall investigation the specific survey responses and more general interview questions were consolidated to generate a set of analyzed expectations that can be seen in Chapter 3 .

\section{Surveys}

The MFR Band consists of forty-nine active duty enlisted Marines and one Warrant Officer. The survey questions used were designed to gauge a Marine's musical expectations before enlisting and during enlistment in the MFR Band. It was important to ask about each Marine musician's level of education to see if that had any effect on their expectations of and experiences in the unit. Of the fifty surveys sent to the MFR Band, twenty five were completed and the survey questions and responses can be found in Appendix A.

The participants who returned the surveys included seven Marines who's highest formal education was a high school diploma, nine who completed some college courses, five who completed undergraduate degrees, and four who had graduate degrees. Those who completed their degrees all had a degree in music. Those who had some college experience included music and non-music degrees. One last fact worth noting is that only three Marines of this group of 
twenty five were on their second USMC Band. The rest had been in the Marine Corps for less than four years.

\section{Interviews for ensemble leaders in the MFR Band from 2017 to 2021}

Eight Marines were selected to participate in the interview portion of this investigation. These Marines were selected because of their varying experiences in the Marine Corps and their tenure as an ensemble leader from the years 2017 to 2021. It was determined that interviews would allow these Marines the best opportunity to describe their experiences, expectations and personal conclusions about their time with the MFR Band.. These questions were designed to elicit responses that would lead to the definition of expectations for potential Marine musicians. All eight participants were given the same questions and the transcripts of their responses may be seen in Appendix B.

Six of the Marines who participated in the interviews were, at the time of writing this document, members of the Marine Forces Reserve Band and had been in the unit for at least two years. One Marine, Gunnery Sergeant Megan Harper, was the Enlisted Conductor at the MFR Band and is, at the time of writing this document, the Enlisted Conductor for the Marine Band San Diego. ${ }^{31}$ These seven interviews were completed on the phone. Staff Sergeant Dee Thomas is currently stationed outside of the country. His interview was completed during an email exchange. 32

\footnotetext{
31 Harper, Gunnery Sergeant Megan. Phone Interview. November 5, 2021.

32 Thomas, Staff Sergeant Dee. Email Correspondence. November, 5, 2021.
} 


\section{Chapter 3: Results}

\section{Analysis of Surveys}

The twenty-five Marines who participated in the survey had differing expectations and experiences during their time in the MFR Band. Seven Marines enlisted after graduating high school while the rest of the survey participants completed some college credits. All seemed to have enlisted for similar reasons but analysis of the survey responses shows that answers from both of these groups (high school graduates and those with at least some college credits) seem to describe different priorities.

Marines without college experience generally have their expectations of the unit met or exceeded. Those with college experience were more critical of their experiences but also offered reasons as to why their expectations were or were not met. One common theme of answers from Marines with graduate degrees and experience in more than one band is that when they described a problem, their answers were more intrinsic and also offered solutions. The Marines with graduate degrees also put more emphasis on the performing and musical expectations. Those with high school diplomas commonly describe that there was an even balance between music and the United States Marine Corps.

Just nine of the survey participants expected to have an administrative duty, though most respondents made effective use of this time. Typically they described their use of this time as an opportunity to develop additional skills such as time management, and in one case a Marine used this opportunity to learn about copyright law. The remaining Marines discussed that an administrative job had only a minimal impact on their musical responsibilities.

One outlier Marine with a degree in music education decided to enlist so that they could "see if they could make it" and did not confess any clear goals. Their responses seem to surmise 
a diminished experience in the Marine Corps as a musician. In another answer, the same Marine admits difficulty finding motivation to improve and shows a pattern of difficulties with problem solving.

The majority of Marines were very forward in presenting the positive and negative expectations and experiences of their time as part of the MFR Band. Many of the Marines describe different traits which improved during their time at MFR. This included things like time management, confidence, attention to detail, and discipline. One piece of advice that the majority of participants disclose is a desire of self-improvement and unit improvement. This theme is very consistent with training received from the recruit training depots. ${ }^{33}$

\section{Comparing Interview Responses}

Eight Marines volunteered to participate in the interviews for this document. These Marines were selected because they led ensembles in the MFR Band from the years 2017 to 2021. Those years were chosen to help ensure that they would participate in the interviews and provide pertinent information. These eight Marines have at least six years of experience in the United States Marine Corps Fleet Bands.

Educational backgrounds of the interviewed Marines are split, with four having college experience and four having enlisted from high school. Interestingly, the majority of their interview answers detail similar sentiments. While not all of these Marines had the opportunity to participate in the Naval School of Music Unit Leader Courses, they all did respond that they received leadership training from a form of mentoring provided by senior colleagues. ${ }^{34}$

${ }^{33}$ Hoque, Faisal. "5 Lessons in Self-Improvement That We Can Learn from the Marines.” Fast Company. July, 2014. Accessed November 1st, 2021. https://www.fastcompany.com/3032699/5-lessons-in-self-improvement-we-can-learn-from-the-marines

34 Box, Sergeant Patrick. Phone Interview. November 9, 2021. 
All eight Marines declared that the likelihood of a command allowing opportunities to lead, create, and perform, are generally in the hands of the Marine who can earn their superior's trust. Trust is earned by being able to at least handle the basic requirements of the job and is then cultivated by succeeding when given more responsibilities. ${ }^{35}$ Mentoring, by an unofficial trainer, is a popular teaching method used and taught by the USMC. ${ }^{36}$

These Marines have all described the freedom to make decisions for the ensembles they have led. Many decisions such as staffing and repertoire are dictated by the need of the unit and the upcoming performance. ${ }^{37}$ Sometimes ensemble leaders will have to deal with outside factors affecting musical decisions such as injuries or PME. All mentioned that ultimately higher ranked and billeted Marines could have final say in decisions, but all operate with the trust of their leadership staff.

When given an opportunity to give advice to offer most chose to talk about finding a healthy balance between being a Marine and being a musician. Being physically fit, PME complete, and leading by example are traits similarly described by the interviewees. As for musical traits, they described included being adaptable and the ability to perform in varying styles and genres. All eight Marines agreed that following this formula would open many doors within the military and as a civilian.

Overall, it is easy to see why these eight Marines have been so successful, each in their own right. They share similar stories about having a trusting leadership staff, mentors who were willing to give responsibilities, and being provided the ability to find a successful formula for

\footnotetext{
35 Hoskins, Sergeant Morale. Phone Interview. October 31st, 2021.

36 Egnash, Martin. “Tailored Guidance Replaces Formal USMC Mentoring Program.” Stars \& Stripes, August 2017.

37 Warmbrodt, Sergeant Lucy. Phone Interview. November 5, 2021.
} 
balancing the Marine and musician aspects of the job. ${ }^{38}$ Their answers may differ in specifics but their message is unified.

38 Wiener, Sergeant Breana. Phone Interview. November 3rd, 2021. 


\section{Conclusion}

As evidenced in the survey, people will always have their own reasons for choosing to enlist in the United States Marine Corps. The surveys and interviews recorded in this document shed some light on the day-to-day requirements, responsibilities, and expectations of being a Marine musician in the Marine Forces Reserve Band.

According to Nigel Lindemann, an author for SurveyAnyPlace.com, the average response rate for online and emailed surveys is about $30 \% .{ }^{39}$ With this in mind, the $50 \%$ response rate this survey yielded was a success. During the time period that this survey was conducted, there could have been a number of performances scheduled, remaining downtime could have been used to complete PME requirements, or there may have been Battalion-wide training taking place, and yet Marines in the unit were still able to respond to the survey in force. The survey responses reflected these varying priorities and responsibilities and endeavored to develop expectations for those interested in this career field.

One unanticipated conclusion is the stark difference in responses from Marines with at least some college experience and those with high school diplomas. These twenty five Marines offered a wide range of musical backgrounds which translated into different priorities. The seven high school educated Marines provided responses which focused on performing in large ensembles. College experienced Marines tended to expect to play more music and did not expect the non-musical responsibilities to play such a large role in daily operations. They also described an adjustment period to find a balance between being Marines and musicians. This was the case in describing their opinion of the administrative aspect of the job and how being a Marine and musician are in tension. Marines without college experience did not think that having an administrative part of the job interfered with their expectations of the job. Lastly, when asked to

39 Lindemann, Nigel. "What's the Average Survey Response Rate? [2021 Benchmark]" SurveyAnyPlace.com, August 9, 2021. Accessed November 23, 2021. https://surveyanyplace.com/blog/average-survey-response-rate/ 
provide advice to those interested in joining this occupational field, the Marines with high school diplomas chose to discuss a theme of mental strength which contrasted with the college experienced Marines who emphasized preparing for two equally important facets of life in the band field; being a Marine and being a musician.

The eight Marines who were interviewed gave advice on how to handle and succeed at the job. Even though the amount and formality of their experience was evenly divided, their answers were still unified. This could be because these Marines had experience in at least one other band and brought those expectations with them to the MFR band. ${ }^{40}$ At some point during the interviews, each Marine also talked about the effect a mentor had on their success in the occupational field. One final commonality these answers shared was when describing problems, they were always followed with solutions.

Chief Warrant Officer Kyne's answer to question eight in the interview best describes a blueprint for succeeding at being a Marine musician. This answer does an excellent job of summarizing the advice Marines wanted to impart for anyone thinking about enlisting as a Marine musician. "A well-rounded Marine musician is someone who takes both the artist aspect and military aspect into their choices. Being physically fit and willing to look out for the Marines in your charge. At some point during your first enlistment, you will be in charge of someone. It is very easy for a fantastic musician to solely focus on themselves. But a well-rounded Marine musician will be a strong player, strong leader of Marines, and set that example. "41

This document establishes a baseline of expectations for those interested in enlistment in the USMC Fleet Bands. This study could be conducted at the other nine USMC Fleet Bands and

\footnotetext{
40 Sylvester, Staff Sergeant Jesse. Phone Interview. November 10, 2021.

41 Kyne, Chief Warrant Officer 2 Eric. Phone Interview. November 13, 2021.
} 
could offer different perspectives based on each band's primary mission. ${ }^{42}$ Possible questions to add to a future survey include "What was the basis of your expectations of this career before enlisting?" and "Did the benefits of this occupation have any impact on your decision to enlist?" Are musicians who enlist with degrees impacted because they already have a degree? What are this system's effects on retention for first enlistment Marines? These questions, which were conceived during the creation of this document, likely constitute their own study.

While the information in this document is specific to the MFR Band, there are aspects that are helpful to describe characteristics of the other United States Marine Corps Fleet Bands. This document established a baseline of expectations for a musician who is interested in joining the Marine Forces Reserve Band and specifically shows that the possibilities for a Marine in the music occupational field are endless.

\footnotetext{
42 Fosler-Lussier, Danielle. "Music and Media in the Service of the State." Music on the Move, 2020.
} 


\section{Bibliography}

Athey, Philip. “Gunny Exhibits ‘Small-Unit Leadership' for Marines Returning from Afghanistan." Marine Corps Times, October 2021. Accessed October 9th. 2021.https:// www.marinecorpstimes.com/news/your-marine-corps/2021/10/01/gunny-exhibits-smallunit-leadership-for-marines-returning-from-afghanistan/

Barnes, Julian E. "Short of Military Brass, NATO Band Soldiers On." Wall Street Journal, July 2016. Accessed October 12th, 2021. https://www.wsj.com/articles/short-of-militarybrass-nato-band-soldiers-on-1467910391

Bolin, Duane. "New Marine Corps Doctrine Promotes Education \& Training." DAC Worldwide, August 2020. Accessed October 27th, 2021. https://dacworldwide.com/new-marinecorps-doctrine-promotes-education-training/

Box, Sergeant Patrick. Phone Interview. November 9, 2021.

Correll, Diana Stancey. "A Culture of Learning: Why the Marine Corps is Promoting Education, Training in its New Doctrine." Marine Corps Times, May 2020.

Egnash, Martin. "Tailored Guidance Replaces Formal USMC Mentoring Program.” Stars \& Stripes, August 2017.

Ellet, William. The Case Study Handbook: How to Read, Discuss, and Write Persuasively About Cases. Brighton, MA: Harvard Business Review Press, 2007.

Fosler-Lussier, Danielle. "Music and Media in the Service of the State." Music on the Move, 2020.

Froeba, Kristine. "Marine Corps Forces Reserve Band Once Again Takes the Streets at New Orleans Mardi Gras." Marine Corps Times, February 2020.

Gleason, Bruce P. "Military Music in the United States: A Historical Examination of Performance and Training." Music Educators Journal, March 2015.

Grames, Ronald E. "Elgar and His Peers: The Art of the Military Band.” The Magazine for Serious Record Collectors, January/February 2018.

Hale, James. "Military Band Alums Dominate George Mason Faculty." Downbeat, February 2019.

Harkins, Gina. "Marines Who Volunteer for Special Duty Assignments Can Earn Thousands 
With New Bonus." Military.com, October 2020. Accessed October 30, 2021. https:// www.military.com/daily-news/2020/10/29/marines-who-volunteer-special-dutyassignments-can-earn-thousands-new-bonus.html

Harper, Gunnery Sergeant Megan. Phone Interview. November 5, 2021.

Herbert, David G. "Another Perspective: Militarism and Music Education.” Music Educators Journal, March 2015.

Hoque, Faisal. "5 Lessons in Self-Improvement That We Can Learn from the Marines." Fast Company. July, 2014. Accessed November 1st, 2021. https://www.fastcompany.com/ 3032699/5-lessons-in-self-improvement-we-can-learn-from-the-marines

Hoskins, Sergeant Morale. Phone Interview. October 31st, 2021.

Kenny, Caitlin M. 'Marine Corps Seeks 'Fundamental Redesign' to Recruiting, Retention, and Careers." Defense One, November 2021. Accessed on November 9th, 2021. https:// www.defenseone.com/policy/2021/11/marine-corps-seeks-fundamental-redesignrecruiting-retention-careers/186600/

Kyne, Chief Warrant Officer 2 Eric. Phone Interview. November 13, 2021.

Lindemann, Nigel. "What's the Average Survey Response Rate? [2021 Benchmark]" SurveyAnyPlace.com, August 9, 2021. Accessed November 23, 2021. https:// surveyanyplace.com/blog/average-survey-response-rate/

Lo, Patrick. "Jane Cross, Master Gunnery Sergeant, USMC, Chief, U.S. Marine Band Library." Music Reference Services Quarterly, July-September 2018.

McNeal, John Jay. "When Identities Collide: A Marine Musician in the Field." The Journal of Military Experience, 2012.

Miller, J. G. "A Successful Military Band Audition." Horn Call: The Journal of the International Horn Society, October 2016.

Mockenhaupt, Brian. “Band Aid.” Atlantic, May 2012.

Phillips, Dave. "Military is Being Asked to March to A Less Expensive Tune." New York Times, August 2016.

Platt, R. Eric. "Marching in Step: Patriotism and the Southern Catholic Cadet Movement." Catholic Historical Review, 2016.

Snyder, Neal. “What About A Military Band?” Teaching Music, April 1996.

Sullivan, Jill M. "Women Music Teachers as Military Band Directors during World War II." Journal of Historical Research in Music Education, October 2017. 
Sylvester, Staff Sergeant Jesse. Phone Interview. November 12, 2021.

Thomas, Staff Sergeant Dee. Email Correspondence. November, 5, 2021.

United States Marine Corps. "Changes To Marine Corps Annual Training and Education Requirements.” MARADMINS 694/20, November 2020.

United States Marine Corps. "Chemical, Biological, Radiological, and Nuclear Defense (CBRND) Policy and Training.” Marine Corps Order 3400.3H, March 2019.

United States Marine Corps. "Marine Corps Combat Marksmanship Programs.” Marine Corps Order 3574.2K, August 2007.

United States Marine Corps. "Marine Corps Martial Arts Program (MCMAP).” Marine Corps Order 1500.59A, September 2019.

United States Marine Corps. "Marine Corps Water Survival Training Program (MCWSTP)." Marine Corps Order 1500.52D, November 2010.

United States Marine Corps. MCDP 1 Warfighting. Wildside Press, 1997.

United States Marine Corps. MCDP 3 Expeditionary Operations. Independent Publisher, 2018.

United States Marine Corps. MCDP 7 Learning. Independent Publisher, 2020.

United States Marine Corps. "Professional Military Education (PME)." Marine Corps Order 1553.4B, January 2008.

United States Marine Corps. "Selecting, Screening, and Preparing Enlisted Marines for Screenable Billets and Independent Duty Assignments (Screenman).” Marine Corps Order 1326.6 CH-1, May 2021.

United States Marine Corps. "Updated Enlisted PME Requirements By Grade." MARADMINS 474/21, September 2021.

Warmbrodt, Sergeant Lucy. Phone Interview. November 5, 2021.

Welborn, Daniel C. "The Soldier-Musician: Professional Opportunities for Recent Instrumental Graduates.” Music Educators Journal, March 2015.

Wiener, Sergeant Breana. Phone Interview. November 3rd, 2021.

Wyman, Richard. "Mission Possible: The U. S. Coast Guard Band and Music Education." Music Educators Journal, March 2015. 
Yi, Capitan Jamison. "MCMAP and the Marine Warrior Ethos.” Military Review, November-December 2004.

Yin, Robert K. Case Study Research: Design and Methods. Los Angeles, CA: Sage Publications, Inc; Fifth Edition, 2013. 


\section{Appendix A: Survey Questions and Answers}

\section{Question 1}

What is your highest level of formal education?

25 responses

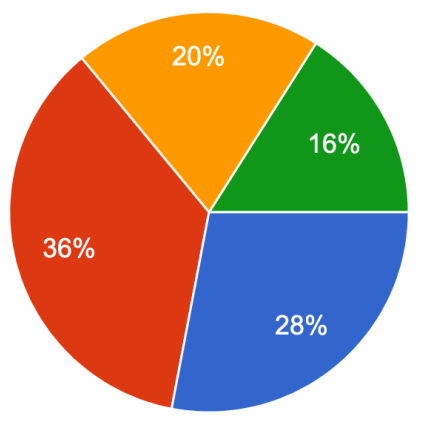

High School

Some College

Undergraduate Degree

Graduate Degree

Figure 7: Pie Chart Answers to Question 1: From the survey Musical Expectations in the Marine Forces Reserve Band, 2021. 


\section{Question 2}

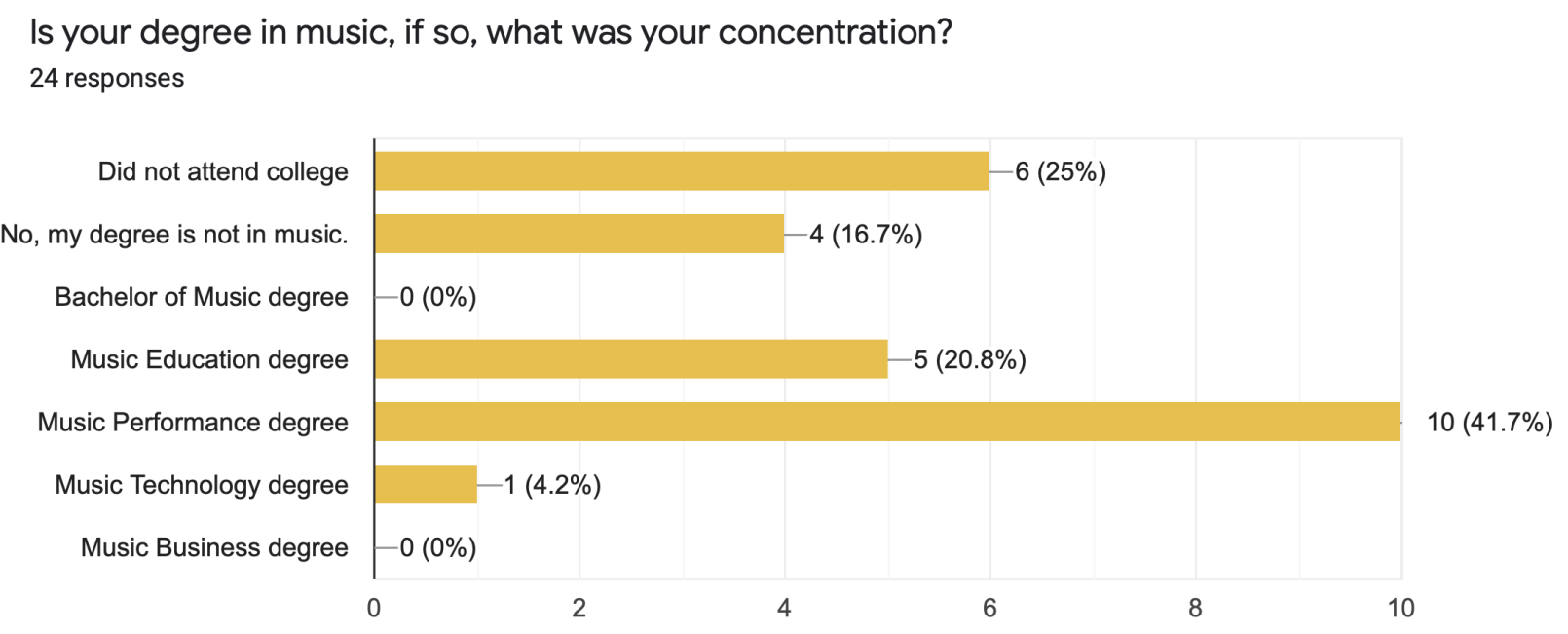

Figure 8: Bar Graph Answers to Question 2: From the survey Musical Expectations in the Marine Forces Reserve Band, 2021.

\section{Question 3}

Does your degree in music help you as a Marine musician?

Question 3 had twenty responses with four participants selecting $N / A$.

- It helps me build my own routine around my schedule to maintain my skill level.

- My degree was in theatre.

- N/A

- It somewhat helps with assisting my coworkers in their musical growth, but I also feel overqualified for my lack of responsibilities/musical requirements as a Marine musician.

- Yes. I may have been able to make it right out of high school but I would have struggled.

- Yes. My degree gives me an advantage in responding to subtle music changes, technical instrument nuances and overall music theory preparedness. 
- I completed 2 years of college and it helped me prepare for the incoming audition and strive for higher expectations.

- No

- No, I haven't focused on playing at all and have not been afforded the opportunity to use my education in rehearsal settings.

- Yes it does. I feel that I am able to offer a different perspective on the music we play through the years that I have spent focusing on music of this genre. I am able to explain my musical thoughts more directly and feel that my experience gains me a degree of credibility on the subject.

- Yes, I constantly draw on my formal education background regarding the musical areas of my job.

- It allows me to lead efficiently and effectively

- I did not finish my degree. But the knowledge I received while in school did allow me to be slightly ahead of the rest.

- Yes. Having higher levels of training in playing an instrument gave me the skills to play more in time, in tune, with a good sound, and stylistically correct. It also allowed me to prepare the music in the time frame expected and gave me troubleshooting skills. My performance degree also set expectations of professionalism and enabled me to interact with my colleagues in a way that is respectful and honest.

- I knew basic theory, which assisted during my entry level training. The rest assisted in minute ways.

- Yes, it does because it applies to 90 percent of your daily tasks.

- Yes, playing at a higher level has made me eligible to play in more ensembles and given me opportunities to lead. 


\section{Question 4}

Were you a professional musician and/or music educator prior to enlisting? If so, please elaborate.

Question 4 had twenty three responses with nine participants selecting N/A.

- No

- N/A

- No, I worked at a restaurant.

- I did freelance work as well as some teaching at the high school level.

- Yes, I taught at two different music schools and performed with three different groups in the Orlando and Southwest Florida area.

- Spent one year freelancing prior to enlisting.

- Did some gigging and a bit of teaching.

- Yes. I played as a professional musician for orchestras, bands, and small ensembles in all sorts of gigs. Sometimes for musicals, concerts, private venues, nuptial ceremonies, etc.

- Yes, I was a music educator. I taught one summer of open class drum corps and two seasons of designing and teaching high-school marching band. I then taught 5-12 music including band, choir, guitar, musical theater, and elementary music.

- Yes I was. Prior to enlisting I was a freelance musician. I performed mostly with orchestras and large ensembles like that.

- I instructed a marching band and indoor marching percussion prior to enlisting.

- Yes- high school band teacher for 6 months 
- Yes, I was an active freelancing musician in upstate South Carolina. Performing, masterclasses to high school students and a private studio. I was also the brass technician for a high school marching band program.

- Not really, but I did take some chamber music gigs now and then.

- Yes, Teaching and performing

\section{Question 5}

How long have you been in the United States Marine Corps?

25 responses
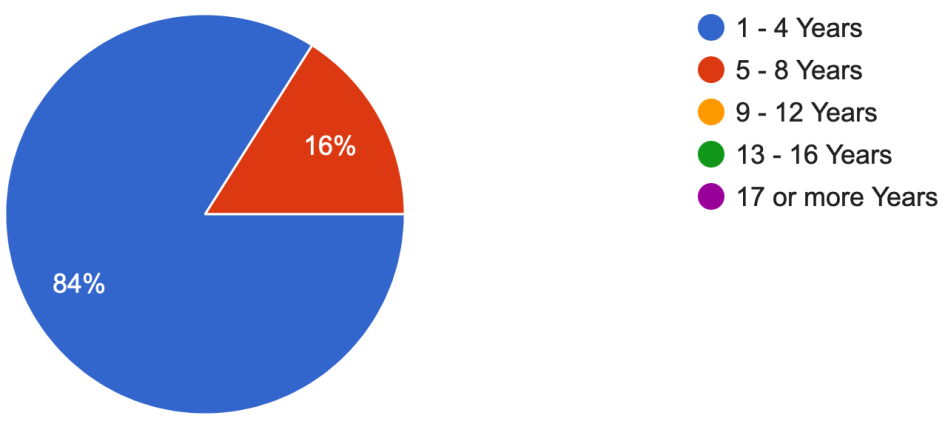

Figure 9: Pie Chart Answers to Question 5: From the survey Musical Expectations in the Marine Forces Reserve Band, 2021. 


\section{Question 6}

How many USMC bands have your served in?

25 responses

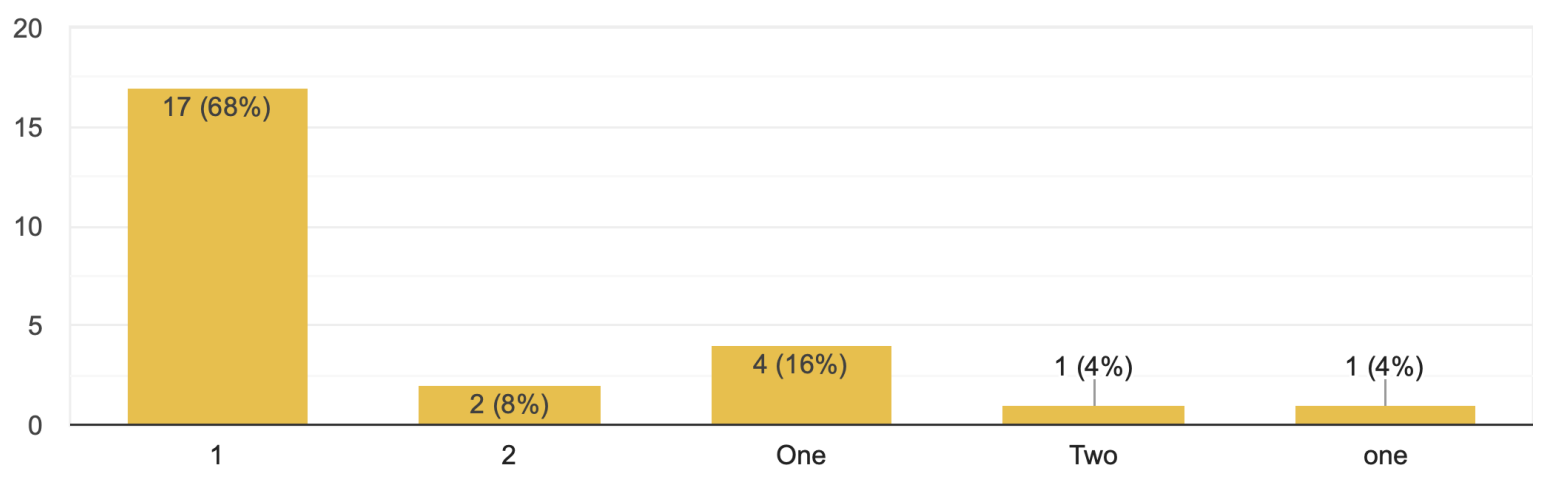

This is the first band for twenty two Marines (88\%).

This is the second band for three Marines (12\%).

Figure 10: Bar Graph Answers to Question 6: From the survey Musical Expectations in the Marine Forces Reserve Band, 2021. 


\section{Question 7}

How many years have you been stationed at your current band?

25 responses

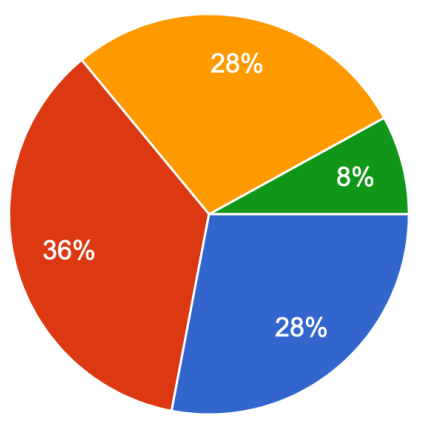

1 Year or less

2 Years

3 Years

4 Years or more

Figure 11: Pie Chart Answers to Question 7: From the survey Musical Expectations in the Marine Forces Reserve Band, 2021.

\section{Question 8}

What are you looking for in being a Marine musician?

- Job security.

- Getting experience in performing for different crowds and testing my limits as a musician with different styles of music.

- To travel to new places and to fulfill my musical needs while also serving my country.

- To be musically challenged, perform regularly, and pushed to grow in different aspects of my life.

- An opportunity to play in the most professional capacity while also serving my country and becoming the best version of myself I can be.

- More musical focus/more challenging repertoire.

- Opportunities to acquire different skill sets and a steady paycheck. 
- Contributing overall in the success of the unit and helping fellow Marines polish their craft.

- To better myself musically and to perform for a variety of audiences across the country.

- I get to use my musical talent while attending college and serving my country.

- I mostly wanted to see if I could and then I did.

- Yes

- First and foremost, I am looking for the opportunity to play my instrument without having to worry about where the next paycheck is coming from. It also feels great to play for so many people who are genuinely excited to see us perform.

- I lacked life direction.

- A high level of music making combined with travel opportunities.

- Full time musician while finishing my degree

- A steady paycheck to perform music and serve my country

- I am looking to serve with musicians with the highest degree of motivation towards their art and what they do.

- Being able to travel and play music while making a sustainable living.

- I was looking for performance experience and to find out if I wanted to actually live the life of a professional musician.

- Travel, new experiences, gain knowledge on my instrument

- To serve and to better my proficiency as a musician

- Just wanted to serve my country by using my music skills

- Opportunity to serve

- A chance to play and do Marine stuff. 


\section{Question 9}

What are the "expectations" versus the "reality" of being a Marine musician?

Question 9 had only twenty four responses.

- My expectations were far exceeded. The Marines senior to me and the staff involved in my career have been much more approachable and competent than I expected. The level of independence granted to the Marines, which was entirely unexpected to me, helps to develop our own sense of personal responsibility.

- I expected to be just playing music all the time, and that is the case with this band, but also realizing that we also do Marine things on the side is the reality. We defend the country, but also keep patriotism alive.

- My expectations were honestly pretty low for the band. I didn't expect to have so many opportunities such as brass band or brass quintet where I'd be learning new types of music. I honestly thought it would only be ceremonies and Christmas concerts. I think the Marine Corps gives the band a lot of liberty for us to do pretty much whatever we want to do, as long as we fulfill the ceremony commitments. The reality is, that we are a ceremonial band first which a lot of people do not enjoy. It's not musically satisfying and it gets old pretty quick. But that's the stuff that we have to do. The other stuff like brass band, big band, combo and rock band are the fun ones and we most certainly are not required to have those ensembles. I think overall there's a good balance between everything though.

- The expectation was to have the time to work on my playing and really grow in a challenging ensemble and to be surrounded by like minded people. The reality is the 
music is not challenging and the majority of the people in the field have a "get the job done" mentality and don't push themselves musically.

- A lot more Marine Corps activities but this band leads us to be constantly preparing for our next performance.

- Expectations: I will play my instrument and make music all day, every day and continually challenge myself to grow into a better player. Reality: the playing takes a back seat. We play easy music in order to be prepared for a performance at any moment. We play the same pieces constantly, so you eventually feel like a living jukebox.

- My expectations involved more field training and possible deployments. The reality is that we do some training (New Orleans hardly does any) but a fleet band hasn't deployed in a long time.

- Certainly being a musician on top of being a marine at first was pretty challenging but I already knew what I was getting into. So my expectations were not betrayed.

- Expectations are to always be musically ready within hours of any performance \& to be a Marine first. Reality is time \& communication is needed to succeed. No one is perfect and mistakes will happen.

- Our primary focus is on performing for Marine ceremonies such as change of commands and retirements. I expected to be more public focused.

- Expectations were I'd be able to use more of my education background to help the unit. The reality was inept leaders were in place when I first got here and did not want anyone in front of the band who could "out teach" them.

- Much more marching and playing as opposed to a concert band setting. 
- The expectation is that most of the day will be spent rehearsing and performing on your instrument. The reality is that there is a great deal of administrative work that you are expected to complete as well.

- The MTA was an excellent salesman. He said that my band would order me the exact equipment that I wanted to play on and that the work day would end at 1400 on most days. Neither of those things turned out to be true.

- Expectations for me were more of a focus on music, reality for me has been more focused on training and Marine duties.

- Expectation: lots of ceremonies. Reality: a lot more fun gigs that I didn't originally think I'd be able to do.

- The expectations were definitely very high, for I was looking to further my music knowledge with different pieces of music literature and to learn more from the musicians who have studied even more into the music realm as I have and uphold the traditions of being a Marine. The reality is that not everyone stresses the same belief and that makes or breaks the whole ensemble, especially with music making. Rather than having others motivate you to be a competitive musician to better themselves and others, they stick to "what gets the job done" and that's it.

- You expect to always play great and exciting music, but in reality you'll sometimes play music you don’t enjoy 100 times.

- I expected to be much less skilled compared to my colleagues. I expected that there would be a high level of musicianship in every individual. I expected a higher degree of organization and communication from leadership. In reality I felt I was a more skilled musician than most others on my instrument and many others in the band. While there were many incredibly skilled musicians in the band, there were enough under qualified 
individuals to be a problem. The leadership did not plan rehearsals well or give musicians time to prepare. It was difficult to plan a week ahead because we would get the next day's schedule less than 24 hours in advance.

- We're expected to perform and act like a professional ensemble, where in reality, some senior leadership do not teach the younger Marines what that means or emulate the expected behavior, they're usually doing the opposite.

- Playing in concert settings more versus marching with military music .

- I expected to play more standard repertoire. It depends on who is your band officer and staff because they kind of decide what music you will play and some of them are open to suggestions which I appreciated. I also expected to do more Marine Corps stuff but that was only during basic training, going to the shooting range once a year, and doing some Professional Military Education courses in person.

- Expected a lot more playing. Reality is we are Marines too.

- I expected more music. Pleasantly surprised with the amount of Marine stuff.

\section{Question 10}

What are some examples of how being a Marine reinforces being a musician?

- The discipline to focus on a task for extended periods of time goes hand in hand with practicing fundamental musical skills. Timeliness, competence, and mutual respect among Marines also plays directly into the professional aspect of musicianship.

- Marines are always improving themselves to be the best they can be and as a musician, that is also a goal. 
- It really makes you want to better yourself, not just for the score or whatever, but you want to meet the level of musicianship that is around you. Our band has so many strong players, it's hard not to want to be as good as them.

- It should reinforce the drive and willingness to never accept that you can't get better.

- Discipline, discipline, and when you're feeling really down and like you can't do it, discipline.

- Being comfortable in a high-stress environment reinforces your ability to perform at a high level when the stakes are elevated.

- Both require spending lots of time and experience to gain mastery.

- Discipline, patience, dedication and being able to adapt to new endeavors.

- Taking time out of the day to better yourself. Schedules will limit the amount of time for individual effort to better themselves.

- You spend most of the work day rehearing or practicing. After the work day ends, you can just stay where you are and keep practicing.

- The discipline from day to day can be applied to practice and self improvement. The hard part is being motivated to apply those concepts to the instrument instead of other things.

- Holding oneself to a higher standard in all aspects

- The biggest impact that being a Marine has on being a musician is reinforcing the discipline needed to maintain proficiency on an instrument. It motivates me to put in the extra hours of practice that I know I need to accomplish both personal and unit objectives.

- Self discipline.

- Both need focus and discipline. 
- Time management and commitment makes you better at practicing and making that practice time more efficient.

- Attention to detail in every aspect of being a marine.

- With the insane amount of motivation that comes from Marines, it would make our drive to hone our skills within our instrument and musicality very high.

- In order for us as musicians to put out a good product it takes individual effort and unit cohesion.

- Discipline is important to both Marines and musicians. Marines and musicians are (ideally) detail oriented.

- Gain discipline and real world experience that translates into music making and being a musician. Ability to attend professional conferences

- The strive for excellence

- The Corps is all about leadership and personal growth in a sense. Once you rank up to Corporal your leaders trust you with more opportunities. For example, I was in a conducting lab. I was also in charge of the clarinet section which made me improve my musical ideas, perception, and quality assurance. The more you rank up the more responsibility they give you which can make you improve in whatever path you'd like to take whether it be conducting, drum majoring, being a small ensemble leader, instrument repair technician, and being an officer.

- Helps instill a stronger sense of discipline, teamwork, and leadership.

- We work as a team, just like in a band. 


\section{Question 11}

What are examples of how being a musician reinforces being a Marine?

Question 11 had only twenty four responses.

- If I am being honest, many of the traits that I possessed due to my musical history were not very conducive to success as a Marine, per se. Being early is about it.

- Musicians are very good at being observant and picky with the little things in music.

Marines always have to look out for the small things because each thing we do affects the unit as a whole.

- I guess the discipline to be a better musician is applicable to everyday life as a marine. That drive to be better and constantly keep improving.

- You should already have the skills of managing problems on an individual level, and have the ability to look at the issue at multiple angles.

- When you receive a tough piece it's like being faced with a challenge, you keep chipping away at it day by day and next thing you know you've got it down.

- Having the discipline to show up every day to work on your craft, and using critical thinking skills to solve problems.

- I believe adaptability is smoother.

- Time management and being capable of doing tasks within a $24 \mathrm{hr}$ limit.

- Being a musician requires some discipline and constant vigor to maintain your skill. The same applies to being a successful Marine.

- Years of rehearsals and self practice has helped as far as applying those skills into other disciplines such as physical fitness, etc. Marching drum corps helped with things like boot camp because the atmosphere was very similar with arguably harder physical 
requirements, so even though I had gotten out of shape prior to enlisting, I was able to push through and get in the swing fairly easily.

- Better keeper of time, time management, work quality.

- Being a musician requires an intense attention to detail. That skill is essential for many aspects of being a Marine as well. It also requires the ability to multi-task which is another important skill that is asked of Marines.

- Attention to detail

- Music forces you to think on a higher level which aids in your decision making process as a Marine.

- Unsure how to answer

- Brilliance in the basics through teamwork and effective communication

- Using analytic skills when we observe ways to interpret music as well as our stamina in being mentally focused would help us use our decision making especially when in field related situations.

- In order for us as musicians to put out a good product it takes individual effort and unit cohesion.

- Musicians tend to have more discipline and detail orientation than the average young marine.

- Having prior knowledge of our job and with a large portion of Marine musicians with upper level degrees lets us translate our previous life experiences into professional military education settings.

- How to listen more in depth and a standard of professionalism

- Musicians have discipline which is what you need to be a Marine. We also know how to work with a diverse group of people. 
- Being a squared away musician allowed me to focus on the Marine side of the job.

- We work as a band, just like a team.

\section{Question 12}

Did you expect to have an administrative component of your job in addition to being a Marine musician?

25 responses

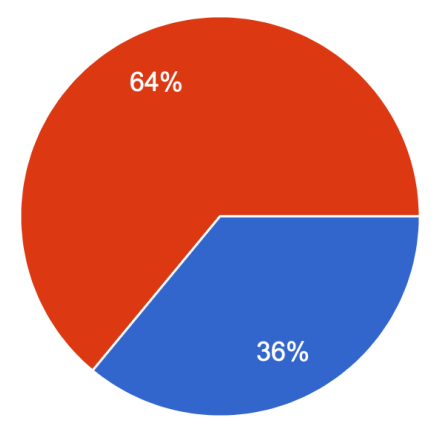

Figure 12: Pie Chart Answers to Question 12: From the survey Musical Expectations in the Marine Forces Reserve Band, 2021.

\section{Question 13}

Has the administrative part of the job had any impact on you as a musician? If so, please provide examples.

Question 13 had only twenty four responses. Seven participants had the same answer.

- No.

- I wouldn't say so. My log area is very flexible with our practice needs. If you need to practice for something, we just go practice and someone else can pick up your log work slack, or you can just finish it later. It's not that intrusive of a job 
- It has helped me learn more about copyright law, organization, and working intimately with people that I may not get along with

- It takes some time away from practice and makes you change your focus but I like having multiple jobs, I think it's good for the mind and keeps things fresh.

- It has had a negative impact. Less time to practice and rehearse. More mental stressors.

- Working in supply at a previous unit and purchasing in New Orleans has given me a new respect for gear accountability.

- Yes, it has deeply widened my outlook on music as a whole. For an example famous composers/arrangers have many more titles than I was aware of, also giving me the opportunity to try out those less popular titles

- Having an admin job makes me more aware of how I need to budget my time in order to accomplish the tasks related to both components of being a Marine musician. It helps build time management and prioritization skills.

- Yes. The more senior you become, the more administrative responsibilities are placed on you and you will have less time to focus on individual musicianship. You have to make time if you want to improve as a musician the higher in rank you go.

- Helped me understand that I need to be multifaceted to be successful.

- Yes it does not allow me to practice as much as I want to.

- Yes, for example in the certain log area I have been a part of, being organized is important so you know where everything is and could rely on situations when you have to provide a piece of work very quickly.

- Through working in the supply section, I was able to learn more about equipment and instrument maintenance and repair. 
- Yes, being a music librarian and chief of the library gave me a perspective of other jobs in music I could perform. It gave me a different view of how I can do my job as well as possible routes I could take in the future.

- Not really as long as I managed my administrative duties and my music proficiency.

- Yes, because I was in the library. When inventorying music I would come across some pieces I had not heard before so I would look them up to try to learn more about those pieces which over the course of three years expanded my music knowledge. Just having access to so many etudes and music resources can be beneficial if you use them.

- Yes, it is necessary but takes time away from doing Marine things and music things.

- Yes, it can get in the way of the day. Sometimes logistical time responsibilities will keep you much later after work.

\section{Question 14}

Do you feel being a Marine conflicts with being a musician? If so, please provide examples. Question 14 had the same response from seven participants.

- No.

- There are certain aspects of creative musicianship that are subdued due to the regimented structure of military style bands. Much of the realm of personal inspiration present in playing has no place in the majority of our job. There is a cap to how much emotion can be poured into a march (though that is not to say it does not take effort to be musical).

- I don't think it does. Especially not in New Orleans. A band like this that doesn't ever go on a single field op, we hardly have to do real Marine Corps things. Being in a relationship with a marine who is in a division band, we have life so much easier. We aren't doing all that Marine Corps stuff, we aren't going to a dry fire machine gun range 
every Wednesday to do gun drills and we most certainly don't ever have to deal with field ops or anything like that. If people have complaints about how being a Marine affects them in New Orleans they need a serious wakeup because we have it so easy and I personally feel pretty lucky to be in this band.

- The biggest part that causes conflict is the inconsistent schedule

- Depends on how "motivated" you are. There are a lot of military tasks that get in the way of playing your instrument. If you want to continually improve, you have to make a lot of sacrifices outside of work (showing up early, staying late, playing during lunch break, etc). Ex: Unit PT, field night, PME courses (LCpl seminar, $\mathrm{Cpl}$ course), rifle range.

- There are not enough hours in the day to truly do everything a Marine musician needs to do. Between the workday rehearsals, logistical duties, physical fitness, PME, personal practice, and fitting in a social life; something always gets put on the back burner. It's usually instrumental proficiency because that is something the rest of the Marine Corps doesn't quite understand so some Marines think it can afford to slip.

- Sometimes I believe pacing myself could be challenging especially when doing physical training. Making sure that I don't overwork and injure myself.

- In this duty station, it does not. We rarely do 'Marine' stuff and it does not conflict with our musical jobs.

- I do, because the "Marine Corps answer " to all musical problems is just try harder and put more time in. A lot of times there isn't any time to be afforded to personal practice. Also my entire time here, the person leading the large groups has had no idea how to rehearse and have an ensemble sound rather than 50 individual timbres. This leads to the individuals not caring or at least not having to put in effort to match sounds. With this in mind I think there is a huge disconnect. 
- I do feel that the obligations of being a Marine interfere with time that could be spent focusing on music. Training requirements such as fitness testing, rifle qualifications, and military education definitely take up a fair amount of time.

- Sometimes: there are definitely times, especially in the rehearsal space, where rank, customs, and protocol can somewhat suppress creativity and devalue the musical ability of others.

- Yes. Apart from the daily time commitments, in my opinion, being a Marine and being a musician are two clashing mentalities. Both can be done, but in my experience, you must learn when to wear the correct "hat".

- The additional duties as a Marine does not allow for excellence in performance

- It shouldn't, especially once you find a balance between the two.

- It interfered with me being a musician. I developed so much tension in my body as a Marine that it made playing a brass instrument much more difficult and almost injured me.

- Unless someone is really organized, being a Marine conflicts in many ways. Having collateral duties and leadership roles cause you to either be very organized or let something else fall onto the back burner, which is usually practicing.

- In a way yes because you don't represent yourself anymore but the United States Military and your personal views might be censored.

- It depends on where you get stationed. If you get orders to Lejeune or Pendleton, you get to do more Marine Corps stuff therefore your practice hours may be affected when you go to the field. If you get stationed anywhere else, you are good.

- I feel that you do not need a high level of playing to be successful in this job. If you do not find a good balance of both, there will be conflict. 


\section{Question 15}

What is one message you would give to potential Marine musicians?

Question 15 had twenty-four responses.

- Get as good as you can get before coming in, and then, if you go to the schoolhouse, get as good as you can while you're there.

- Be ready to be on a grind for a while when it gets busy, but also when times get tough, remember why you are doing this.

- Make a decision on why you're becoming a Marine musician, and stick to that. Don't let others cloud your goals.

- Since you're in the band you have to literally be the best Marine you can be, nobody wants to be outran or out-lifted by a band member, but every band member should want to do these things.

- There are a lot more military components to the job, so if you want to be a professional orchestral/band musician, this may not be the place for you. If you enjoy music but it's not your \#1 focus, then you won't regret joining.

- Make yourself as multifaceted as possible. There is more to the job than playing music. Especially as you gain more rank.

- Pace yourself, believe in yourself and within your own mind setup your goals and objectives for success.

- Take opportunities to be better than yesterday. There are resources handed out by the military to be better. Lessons, conventions, clinics, etc are available, so communicate with your chain about attending them. 
- Don't wait until you are a higher rank to grab opportunities. As a junior Marine, you still have the opportunity to influence your unit.

- Do your research and be prepared to do a lot of stuff you probably don't want to do. Ooh Rah.

- Just like anything in the Marine Corps, it's not easy. It requires hard work and dedication to duty.

- Be ready for non-musical obligations to be a large focus of life. There are many challenges to overcome before you are allowed to focus on music. However, you have the opportunity to have a major impact on many people through your performances.

- Be mentally flexible.

- Do your research before making a decision. I love being a Marine, but if playing your instrument is the only thing you want to do, perhaps the Marine Corps isn't for you. There are many highly accomplished musicians that I know in the Marine Corps, but it takes extreme hard work and diligent time management to be an "elite" musician in the Marine Corps. On the other hand, if you enjoy music, are a competent instrumentalist but prefer a more "balanced" experience, then the Marine Corps may be a good fit.

- It's worth every bit of training and obstacles to be able to say you play your instrument full time for a steady paycheck.

- It is a rewarding way to honor service members that came before you and gives you a sense of purpose within the greater scheme of the organization

- Don't let others pressure you into thinking what is "cool" to the point where what could've been your biggest strength grows to be what could've been. It'll happen that those people are the ones who bring the performance level down to their lack of work 
they put into themselves. Keep working as hard as when you first decided to join and find those on the same path!

- Really understand what it is we do as Marine musicians and be sure that is what you want.

- Talk to many current and former Marine musicians to find out if it would be the right fit for you.

- Really think about your options, do your research into the other military branches, and why you want to do this, and what your end goal is. Have a backup plan and a backup for your backup.

- Don't lose faith, keep practicing, and don't be afraid to ask questions (at the appropriate times).

- If you are thinking about joining, I just want to say that it is a safe choice that could be beneficial for you and your family because of housing allowance, full medical, etc. The longer you stay in, the more money you get and you can possibly retire early. Most Marines want to get out in their first enlistment which is normal not just for musicians but for Marines in general. Every job has people who you like or dislike but just remember that the more you rank up, the more you can affect your unit for the better.

- Find those that are successful and find a way to emulate them.

- Be squared away. If you can be trusted to do the basic shit, then they will trust you to do the fun stuff too.

\section{Question 16}

What experience(s) with the USMC best epitomizes your service? 
- Virginia International Tattoo was a great experience because the show encased exactly what we do. We fight for the U.S. but we also play music for the people. After every performance, we always got the loudest cheer from the crowd and the audience came up to us after the performance to tell us how great we were. I joined to use my musical abilities to perform for people. Being in one of the top military bands in the country is putting me to work and it is extremely satisfying to see that work pay off in happiness for both the audience and me.

- I don't really have a single moment that epitomizes my short time in the Marine Corps yet. I have favorite memories such as going to NYC with the brass quintet, going to Norfolk, Virginia and all the other little trips we've done. I think the experiences that honestly matter the most to me would be the times I've spent with my friends, either at work or outside of it.

- I have been able to find and experiment with ways to self motivate through the job, and implement that into my performances. It is difficult to give a specific example because of the many different situations I've found myself in.

- Working hard and showing initiative and not just doing the status quo, people won't notice the first day, and the second, but eventually they do and that's when the positive feedback loop begins.

- "Sometimes you have to do the 'green' stuff in order to get back to making music" - a wise Sergeant.

- I really enjoyed the Jazz Orchestra tour the one time I was chosen to go.

- Being able to serve is my greatest service.

- Public speaking has been a good experience to step outside of my bubble. 
- After months of practice, I passed my final music assessment at the Naval School of Music. The very next day, I began spending 4-5 hours a day participating in the Marine Corps Martial Arts Program. In the span of a month, I spent hours on both the Music side and the Marine side of my job, and it brought me tremendous pride knowing that I was able to accomplish both.

- I feel that I have been severely underestimated until recently. Almost incentivized to not care and coast, which led to me being even more underestimated. It has been fun though.

- Traveling.

- Playing Taps for a former Secretary of State's funeral.

- The travel opportunities and experiences during my time in the Marine Corps are ones that I would never trade for anything.

- Not sure how to answer this one, sorry.

- The experience happened to be with the Woodwind Quintet and Quartet for all of our performances. The rest of the unit in the large ensemble was still at the base. The music we played, the level of musicality in the ensemble, the cohesion between the group and the excitement of performing as well as being over what we were expecting to be.

- Meeting and performing for the Navajos Code Talkers at the Navajos Code Talkers day celebration in Arizona.

- Driving from NOLA to Mississippi to play for the

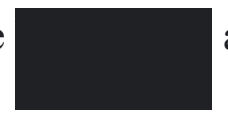
an hour before a hurricane was expected to hit and driving back a few days later through the storm's remnant. Performing for public audiences throughout the country.

- Performing Taps for military funerals.

- Performing for the Navajo Code Talkers.

- Performing at the Houston Rodeo. 
- Skills I gained as a leader, how to run and manage a section of trumpet players and the skills I gained as a music librarian.

- Ceremonies.

- Playing one of my favorite clarinet concertos as a featured soloist.

- We played a gold star concert at a reserve air station. Our program was primarily marches and it was one of the best musical experiences I have been a part of. We performed as a team and all bought into the conductor's ideas for the concert.

- Performing at Mardi Gras. 


\title{
Appendix B: Interviews for ensemble leaders in the MFR Band from 2017 to 2021
}

\author{
Sergeant Morale Hoskins, tuba \\ Orange City, Florida
}

1. Did you have experience leading/conducting ensembles prior to your time in the USMC? If so, please elaborate.

Sgt Hoskins: Yea a little bit in high school doing solo and ensemble stuff with tuba euphonium quartets and brass quintets but nothing like the brass band and jazz fusion ensembles.

2. What training has been provided by the USMC to help you prepare for your role as an ensemble leader?

Sgt Hoskins: I wouldn't consider it formal training but most of what I've learned is from watching others lead. Back in high school getting to be a part of small ensembles and copying things from leaders I liked and not repeating things I didn't like. The biggest help was actually leading an ensemble in the Marine Corps and asking for feedback from my colleagues. I hope that answers the question, there wasn't any formal training because I didn't go to the Unit Leaders course.

3. Please elaborate on any formal or informal musically relevant training opportunities you have experienced.

Sgt Hoskins: As far as formal training, I've taken lessons on tuba since I was thirteen. Those helped me overall as a musician later on in life. The same with taking music theory classes in 
high school helped with arranging music and score study. I'd say most recently performing in brass bands in New Orleans has been the biggest help. Most of what I learned was during rehearsals with these groups, which is a very different environment than the Marine Corps. There is rarely any sheet music in front of you so most of it is done by ear.

4. What opportunities are available for you to lead traditional and non-traditional ensembles? It comes with time.

Sgt Hoskins: Once you first join there won't be a lot of opportunities. You can be in those ensembles but won't lead one until a little later after you gain rank. Being a Sergeant for a few years, I have had the opportunity to lead several ensembles. Most of the time now I am talking to higher ranking Marines and offering a chance for less experienced Marines to lead. Most of it is opportunity too, which instrument you play. Tuba is going to play in more ensembles than euphonium. But that doesn't go to say that those opportunities aren't there.

5. As an ensemble leader, do you feel that you have control over personnel, repertoire, and other musical decisions?

Sgt Hoskins: To an extent, I get to make my recommendations to my supervisor about personnel, but it kind of comes down to needs of the entire unit. As much as you want the best players all the time, that isn't feasible. As far as repertoire, I've never had an issue making choices but I always try to ask the group what we want to play. At the same time, staff have trusted my decisions to pick the most appropriate music for us to play.

6. Are you able to program musically fulfilling repertoire? 
Sgt Hoskins: I would like to say yes. Going back to the personnel issue, we all have varying abilities. So we need to find this happy medium for the ensemble. Some members will love the rep and some may not. We always push to find the balance between challenging and fun.

7. Is there any reason the USMC would preclude you from making programmatic decisions? Sgt Hoskins: The only way I could see that happening is that previously you were given freedom to choose repertoire for a performance and failed to pick the most appropriate piece. Otherwise, I don't see why that would happen.

8. What does being a well-rounded Marine musician mean to you?

Sgt Hoskins: For me, we always talk about us always always being a Marine first. Shooting well on the rifle range and your ability to lead Marines and not just musicians. On the musical side, there's being able to play varying genres of music. In the civilian world you can focus on one style of playing but being a Marine means being able to succeed in different ensembles and genres.

9. What kind of doors does being a well-rounded Marine musician open (professionally and musically)?

Sgt Hoskins: That is how you get into a position to be in charge of ensembles. Getting to be an instructor at the Naval school of music and stepping into a leadership role. You need to be an awesome player and mentor to incoming Marine musicians. It will help accelerate your career advancement. 
Sergeant Breana Wiener, horn

Brigantine, New Jersey

In addition to her horn MOS, Sergeant Wiener volunteers to be the lead singer of the MFR

Rock Band and vocal soloist for the unit.

1. Did you have experience leading/conducting ensembles prior to your time in the USMC? If so, please elaborate?

Sgt Wiener: I was a high school drum major.

2. What training has been provided by the USMC to help you prepare for your role as an ensemble leader?

Sgt Wiener: No formal training has been provided but I have had on the job training.

3. Please elaborate on any formal or informal musically relevant training opportunities you have experienced.

Sgt Wiener: I got to do some conducting classes. I also got to train with the President's Own for a week taking horn lessons and learning about how they conduct their PAO section.

4. What opportunities are available for you to lead traditional and non-traditional ensembles?

Sgt Wiener: There are a lot of opportunities because some of our colleagues created ensembles.

Even if you're not the billeted leader there are still opportunities to lead ensembles. 
5. As an ensemble leader, do you feel that you have control over personnel, repertoire, and other musical decisions?

Sgt Wiener: I believe so. Personnel would be more of an SEL decision. But repertoire is up to us. At my previous band, our music was picked for us and it wasn't fun. Here as a vocalist, I have more say in the music I will sing and we can cater to our audience.

6. Are you able to program musically fulfilling repertoire?

Sgt Wiener: Yes we are able to make those decisions for the rock band.

7. Is there any reason the USMC would preclude you from making programmatic decisions? Sgt Wiener: No, unless the song had a bad meaning behind it.

8. What does being a well-rounded Marine musician mean to you?

Sgt Wiener: Being solid in your craft while also being solid on the Marine side of the job. Showing up to work on time, trying your best, doing the right thing, and being a good leader to your colleagues and subordinates.

9. What kind of doors does being a well-rounded Marine musician open (professionally and musically)?

Sgt Wiener: I will not be doing music after my time in the USMC. But it opened doors for my potential Master's programs as I have been accepted to all the schools I've applied to. They see that I was a musician in the Marine Corps and it gives the perception of being well rounded as a leader. I feel that I am a step above my peers. 


\section{Sergeant Lucy Warmbrodt, saxophone}

Dunkirk, New York

1. Did you have experience leading/conducting ensembles prior to your time in the USMC? If so, please elaborate?

Sgt Warmbrodt: Yes during a college conducting class. But I never led anything musically until the Marine Corps.

2. What training has been provided by the USMC to help you prepare for your role as an ensemble leader?

Sgt Warmbrodt: The Unit Leader Course, Live Production Technicians Course and the Professional Military Education at each grade (rank). Within the ULC there were ensemble rehearsal techniques leading a variety of ensembles. Drum majoring and band management were other areas of focus. We were also provided applied lessons during our time at the ULC.

During the Live Production Technicians Course we learned sound and lighting logistics, leading a crew on set up. PME helped make better and more informed ranks.

3. Please elaborate on any formal or informal musically relevant training opportunities you have experienced.

Sgt Warmbrodt: Attending conferences such as the JEN. Music clinics such as the Gordon Goodwin Clinic in California. Touring with the USMC Jazz Orchestra. During a school visit, you 
have the opportunity to lead a section, teach a private lesson, or lead a rehearsal. We have the opportunity to perform with civilian ensembles.

4. What opportunities are available for you to lead traditional and non-traditional ensembles?

Sgt Warmbrodt: Yes, there are opportunities. But like anything else, it will depend on staffing and the leadership of the unit. If you are granted permission, you could lead any ensemble. You have the opportunity to create and lead any non-traditional ensemble. Will you get performance opportunities with your non-traditional group? That would depend if there was a need for that ensemble to perform. There are endless opportunities if permission is granted. It is easier to get permission if you are presenting a more polished product.

5. As an ensemble leader, do you feel that you have control over personnel, repertoire, and other musical decisions?

Sgt Warmbrodt: Yes but it is subject to change at a given notice. Band Leadership will always have the freedom to step in and give their input. The Band Officer will always have the final say.

6. Are you able to program musically fulfilling repertoire?

Sgt Warmbrodt: Yes. You are chosen to lead and the assumption is that they selected you for a reason and will support you and set you up for success.

7. Is there any reason the USMC would preclude you from making programmatic decisions? Sgt Warmbrodt: If there was a disagreement over the desired product. 
8. What does being a well-rounded Marine musician mean to you?

Sgt Warmbrodt: To me it means balancing the responsibilities of being a Marine and musician. In that you are constantly striving to be better at both and not letting one outweigh the other. Sometimes you will have Marines who lean on just one aspect to help them get by. It is almost like trying to find that balance between oil and water.

9. What kind of doors does being a well-rounded Marine musician open (professionally and musically)?

Sgt Warmbrodt: It allowed me to lead small units as a junior Marine. I went to advanced training much earlier during my career than my peers. I was promoted early and developed a rapport with the other Marine musicians from other duty stations. I have the opportunity to work closely with higher ranking Marines and not feel awkwardness because of the gap in rank. That applies to outside of the band occupation as well. Those are just a few of the opportunities made available to me, there really is no limit to it.

\section{Staff Sergeant Jesse Sylvester, trombone} Fort Collins, Colorado

1. Did you have experience leading/conducting ensembles prior to your time in the USMC? If so, please elaborate?

SSgt Sylvester: No, I took one conducting class in College. As far as leading ensembles, no prior experience.

2. What training has been provided by the USMC to help you prepare for your role as an ensemble leader? 
SSgt Sylvester: Once I entered the fleet and was leading ensembles, most of the training I used was from what I learned in college. The Naval School of Music teaches more about how to be a Marine in the fleet. I relied heavily on experience prior to enlisting.

3. Please elaborate on any formal or informal musically relevant training opportunities you have experienced.

SSgt Sylvester: As far as training opportunities I'm going to go back to my training at my undergraduate university. Something very important to me was on the job training. In the Marine Corps any time I've had to lead musically and non-musically, the best experience was just leading. I am continuously learning and growing. Learning from mentors and trial and error to help create my own style of leadership.

4. What opportunities are available for you to lead traditional and non-traditional ensembles?

SSgt Sylvester: It's all about if you are qualified to lead ensembles then most likely you'll be able to create that opportunity. Put in that time and earn the leadership's trust, then you can have any opportunity to lead.

5. As an ensemble leader, do you feel that you have control over personnel, repertoire, and other musical decisions?

SSgt Sylvester: I've only had the opportunity to lead small ensembles but Yes. When I've led them it has always been $100 \%$ my decision. Personnel is a little different and based on the needs 
of the unit. The SEL will also have final say over personnel. But they are always reasonable and willing to work to please everyone.

6. Are you able to program musically fulfilling repertoire?

SSgt Sylvester: This job is all mission oriented. So if the music makes sense for the situation then there is no reason it can't be fulfilling. It also depends on what kind of effort you put into reading and learning new repertoire. It can get unfulfilling when we just rely on the same handful of music over and over. It all comes down to your mindset.

7. Is there any reason the USMC would preclude you from making programmatic decisions? SSgt Sylvester: Is the ensemble capable of performing the program? Is there enough time to prepare it? Is it appropriate for the audience? Keep in mind that if you were put into a position to lead an ensemble, you would have already thought through these questions. So I feel there are very few reasons for your ideas to be denied.

8. What does being a well-rounded Marine musician mean to you?

SSgt Sylvester: Adaptable. In my opinion being a musician and Marine often have clashing mindsets. You have to be able to wear different hats. Ask yourself, "am I in Marine mode or in musician mode?" My Marine mindset leads me to act differently, make different decisions, and carry myself differently. As opposed to being an artist I need to use more emotions. You want to beware of pigeonholing yourself. Don't be inflexible and unable to play in different genres. You also need to balance that with staying on top of your training requirements. Being able to balance being mentally and physically fit. 
9. What kind of doors does being a well-rounded Marine musician open (professionally and musically)?

SSgt Sylvester: It gives you more opportunities. If the leadership trusts you you can be useful to the unit in so many ways. If you are squared away and seek new opportunities to lead or perform, you'll have a higher chance of having requests granted. The opportunities are almost endless if you are able to handle the basic responsibilities of the job.

\section{Sergeant Patrick Box, trombone Augusta, Georgia}

1. Did you have experience leading/conducting ensembles prior to your time in the USMC? If so, please elaborate?

Sgt Box: Yes, I taught middle school, high school, and college ensembles for ten years.

2. What training has been provided by the USMC to help you prepare for your role as an ensemble leader?

Sgt Box: There was on the job training and mentoring from the EC at Parris Island. I also went to the Unit Leader Course to learn conducting techniques from each billet.

3. Please elaborate on any formal or informal musically relevant training opportunities you have experienced. 
Sgt Box: I have a bachelor's and master's degree in music education. In the Marine Corps, the ULC has a class that is all about rehearsal techniques. We are taught how to detect, isolate, and correct errors. We also have conducting and drum majoring classes.

4. What opportunities are available for you to lead traditional and non-traditional ensembles?

Sgt Box: Personally it's mostly getting to lead the ceremonial band in military ceremonies and civilian parades.

5. As an ensemble leader, do you feel that you have control over personnel, repertoire, and other musical decisions?

Sgt Box: Yes within reason. I always run things by the Band Officer, but I am usually given the freedom to do what is needed.

6. Are you able to program musically fulfilling repertoire?

Sgt Box: I think it is more of a challenge with adding movement to playing. As much as we try to keep things fresh, part of it is finding something that works and sticking with it. Parades typically won't be very fulfilling as we will lean on playing more crowd pleasing music.

7. Is there any reason the USMC would preclude you from making programmatic decisions? Sgt Box: I suppose it would just depend on the OIC and how hands on they want to be.

Sometimes we will make decisions based on perceived appropriateness. For example, on Parris Island we performed a medley and the last tune of the medley had "Dixie" in it. We decided to cut it from the program for political perceptions due to the political climate. 
8. What does being a well-rounded Marine musician mean to you?

Sgt Box: Being a military musician is about being a complete player. You can't enlist thinking that you're a classical trombone player. We're going to need you to play in a concert band, then move right into big band, then go play a brass band solo, and finish a concert with a brass quintet. You are not afforded the opportunity to be a specialist.

9. What kind of doors does being a well-rounded Marine musician open (professionally and musically)?

Sgt Box: If you're trying to make this a career, the more well rounded you are then you will be perceived as an asset and will open up more opportunities to lead varying ensembles. Outside of the Marine Corps will have benefits if you decide to stay in a music field. You'll be more competent in a wider variety of musical settings.

\section{Gunnery Sergeant Megan Harper, oboe Wellington, Florida}

1. Did you have experience leading/conducting ensembles prior to your time in the USMC? If so, please elaborate?

GySgt Harper: Yes. I had a woodwind trio throughout college. No conducting experience.

2. What training has been provided by the USMC to help you prepare for your role as an ensemble leader?

GySgt Harper: I wasn't an ensemble leader from the beginning based on my prior experiences. No formal training until the ULC. It was four and a half years after first enlisting until I started 
the ULC. After that I started conducting the band at Parris Island. Then I had informal training from the Band Master and Band Officer at Parris Island. I took a lot of gigs during that time and came to MFR and eventually was selected to be the EC. I was eligible to become the EC earlier but chose to wait an extra two years before officially becoming the EC.

3. Please elaborate on any formal or informal musically relevant training opportunities you have experienced.

GySgt Harper: I took two semesters of conducting at my undergrad. My college band director took time to spend time on rehearsal technique and philosophy. My technique was honed in because of Dr. Bobby Adams. It made me a better leader and conductor. At the ULC, they teach DICMO. It is specific to error detection, detect, identify, correct, and move on. Outside of that, nothing has been more helpful than putting time on the podium. It is your responsibility to inspire and keep the ensemble buying into your ideas. Nothing can replicate having young conductors putting time in front of ensembles.

4. What opportunities are available for you to lead traditional and non-traditional ensembles?

GySgt Harper: When I was an E-3 to E-5, I led the woodwind quintet. As an oboe instrumentalist, I was not going to be leading the brass band. Parris Island focused primarily on patriotic music. But coming to MFR, I had to become comfortable conducting New Orleans standards. Here in San Diego, our focus is more on pop music. I don't think it's in anyone's best interest for me to lead a big band. I could, you just may not want me to. 
5. As an ensemble leader, do you feel that you have control over personnel, repertoire, and other musical decisions?

GySgt Harper: I have minimal control over personnel due to appointments and duty status. For example, let's say out of four tubas in the ensemble, I could have one away at training, one with a light duty status, another player was sent to the hospital, and for a period of time I was left with one tuba. Situations like that have happened with several sections. In terms of repertoire we cycle through sets of a march and pop tune combo. I do have control of the pouch tunes and rotate music appropriately (Marine musicians are issued a small binder or pouch of about thirty marches which should be performance ready at any given moment. Pieces selected for the pouch vary from unit to unit). I do have control over the concert band repertoire. Mission will dictate. For example, when we play at universities for the MFR tours, we will play more challenging music. Here in San Diego, our mission is different and we have fewer concert band performances.

6. Are you able to program musically fulfilling repertoire?

GySgt Harper: Yes, but I do. But it is not the conductor's obligation to exclusively consider musical fulfillment as the number one priority for programming. We need to keep the audience in mind. If a march is performed really well, then who is to say that it is not musically fulfilling. If we are working together and have everyone on the same page and things are going really well then it will be musically fulfilling.

7. Is there any reason the USMC would preclude you from making programmatic decisions? GySgt Harper: I don't think so. There are topics that are inappropriate for our narrations for performances but you will have that anywhere. 
8. What does being a well-rounded Marine musician mean to you?

GySgt Harper: You have to do everything. To be a well-rounded Marine musician, you need to be able to hang on your instrument regardless of your billet or rank. I'm an oboist primarily and have been called on to perform recently. The physical expectations are so low due to having more tenure. If you're a well-rounded Marine musician then you need to be able to perform physically at a high level. I have found that Staff NCO's tend to be the least willing to be uncomfortable. They tend to feel that they have "earned it " and that is not what service is about. To be a well-rounded Marine musician we need to be able to represent both music and the Marine Corps in a way that each institution would be proud to have us in its ranks.

9. What kind of doors does being a well-rounded Marine musician open (professionally and musically)?

GySgt Harper: The Marine Corps, by nature of the job, requires you to humble yourself. You must set your pride aside and be part of the team. So this job is good for that. Having smaller numbers, it puts the onus on the player to be able to perform. As for the civilian side of things, when 18-22 year olds leave the Marine Corps, they are set up for success. Their expectation of a professional working environment is much higher than what is out there. Whether or not they choose to follow that is up to them.

\section{Staff Sergeant Dee Thomas, trumpet \\ Poughkeepsie, New York.}

1. Did you have experience leading/conducting ensembles prior to your time in the USMC? If so, please elaborate?

SSgt Thomas: I did not have any prior experience. 
2. What training has been provided by the USMC to help you prepare for your role as an ensemble leader?

SSgt Thomas: While the Marine Corps does offer training at the Navy SOM, I did not return to complete the course. Most of the training I received was from senior leadership and those who had college experience. Other training was through attending clinics and master classes.

3. Please elaborate on any formal or informal musically relevant training opportunities you have experienced.

SSgt Thomas: There have been few master classes I have been fortunate enough to attend. Some of these were for the entire unit, while some were more personalized. For instance, I was able to attend a master class led by the renowned trumpeter, Alan Vizzutti. I have also been fortunate to attend the International Trumpet Guild and the Midwest Clinic.

4. What opportunities are available for you to lead traditional and non-traditional ensembles?

SSgt Thomas: Depending on the instrumentation, the opportunities to lead an ensemble are limited. A Marine musician is normally selected to lead an ensemble based on their leadership abilities tied in with musical capabilities. As far as non-traditional ensembles, if you have an imagination, you can convince others to join during non-working hours. Non-traditional ensembles have been on the rise in recent years. Hopefully, they continue to grow.

5. As an ensemble leader, do you feel that you have control over personnel, repertoire, and other musical decisions? 
SSgt Thomas: I tend to focus on collaborative effort where the entire ensemble has the opportunity

to make decisions. The product is normally better off if we understand each other and how we each interpret the music. This way allows multiple options to choose prior to making the overall decision as a group. This works better in smaller settings such as brass quintet.

6. Are you able to program musically fulfilling repertoire?

SSgt Thomas: This question is based on personal preference. What is musically fulfilling to one person will not necessarily be the same for another.

7. Is there any reason the USMC would preclude you from making programmatic decisions?

SSgt Thomas: In a way, yes. Audiences attending performances by military bands generally have an expectation of patriotic music. Also, there is repertoire out there which is not appropriate for some audiences.

8. What does being a well-rounded Marine musician mean to you?

SSgt Thomas: Being a well-rounded Marine musician means having the best of both sides. Being able to endure the physical and mental challenges of a Marine while also maintaining proficiency on your instrument. This is no easy task and takes a lot of time and effort. One must be willing to do both because we never know when our nation will call upon us and we also must provide a good musical product for our audiences.

9. What kind of doors does being a well-rounded Marine musician open (professionally and musically)? 
SSgt Thomas: I cannot say for sure. There are many opportunities for you to connect with people from performances. Networking is the key to getting your foot in the door for whatever the plan is for the future. If you strive to do your best, doors can open for you.

\section{Chief Warrant Officer 2 Eric Kyne, saxophone West Hartford, Connecticut}

1. Did you have experience leading/conducting ensembles prior to your time in the USMC? If so, please elaborate?

CWO2 Kyne: I had zero experience conducting. I joined right out of high school. I did have experience leading quartets, quintets, and jazz combos from high school and after school programs.

2. What training has been provided by the USMC to help you prepare for your role as an ensemble leader?

CWO2 Kyne: So much. Between attending the intermediate and advanced music courses, the sound reinforcement course (live production technician course), I received more opportunities to lead ensembles. That live training helped tremendously.

3. Please elaborate on any formal or informal musically relevant training opportunities you have experienced.

CWO2 Kyne: One of the biggest helpers was C.E.R.T. (Contemporary Ensemble Rehearsal Techniques) Class. It led us into D.I.C.M.O. (Detect Isolate Correct and Move On) which was 
very crucial because I could hear an error, work on it, and move one so that an entire rehearsal wasn't wasted trying to work out something.

4. What opportunities are available for you to lead traditional and non-traditional ensembles?

CWO2 Kyne: That all depends on your leadership. If they are good and understanding they will put out opportunities to lead. But if it is more centralized those opportunities can be bare. For example, the MFR Jazz Fusion ensemble is a cool unique ensemble which Marines created all on their own. So we let them do their thing. As opposed to the mindset of "oh well this is a unique ensemble which no one will appreciate. It all depends on how pragmatic the leadership is.

5. As an ensemble leader, do you feel that you have control over personnel, repertoire, and other musical decisions?

CWO2 Kyne: I feel our Marines would say that they feel they have control. We are good about delegating that leadership down. For me particularly, I don't want the same great players in every ensemble. We all signed up to do the job. It's also not practical to have the same handful of players performing everything. Our schedule does not allow it. I am confident that the Marines can handle personnel decisions using the majority of the band.

6. Are you able to program musically fulfilling repertoire?

CWO2 Kyne: Yes, this has been the case ever since I joined the Marine Corps. Small ensembles have had total say over the repertoire they select.

7. Is there any reason the USMC would preclude you from making programmatic decisions? 
CWO2 Kyne: I wouldn't use the word preclude. But there will be situations where performance requests will look for a specific genre of music. Holiday themed music, patriotic music, or solemn music are some examples of genres asked for.

8. What does being a well-rounded Marine musician mean to you?

CWO2 Kyne: A well-rounded Marine musician is someone who takes both the artist aspect and military aspect into their choices. Being physically fit and willing to look out for the Marines in your charge. At some point during your first enlistment, you will be in charge of someone. It is very easy for a fantastic musician to solely focus on themselves. But a well-rounded Marine musician will be a strong player, strong leader of Marines, and set that example.

9. What kind of doors does being a well-rounded Marine musician open (professionally and musically)?

CWO2 Kyne: In the Marine Corps it will open doors to future service as a staff NCO or officer, B billets, becoming an officer outside of the band field. I've seen strong musicians join recon or public affairs. For the civilian side, people have an expectation of your work ethic and dependability. They expect all those intangible qualities. I know people who are working at the Pentagon, to people who are business leaders, and those who are civilian musicians. 